\title{
11. BURIAL TRANSFORMATION OF SEDIMENT FABRIC AT OCEAN DRILLING PROGRAM SITES IN THE WESTERN ARABIAN SEA ${ }^{1}$
}

\author{
J. Sybil Callaway ${ }^{2}$ and William H. Busch ${ }^{2}$
}

\begin{abstract}
The fabric of sediments recovered at sites drilled on the Indus Fan, Owen Ridge, and Oman margin during Ocean Drilling Program Leg 117 was examined by scanning electron microscopy to document changes that accompany sediment burial. Two sediment types were studied: (1) biogenic sediments consisting of a variety of marly nannofossil and nannofossil oozes and chalks and (2) terrigenous sediments consisting of fine-grained turbidites deposited in association with the Indus Fan. Biogenic sediments were examined with samples from the seafloor to depths of $306 \mathrm{~m}$ below seafloor (mbsf) on the Owen Ridge (Site 722) and $368 \mathrm{mbsf}$ on the Oman margin (Sites 723 and 728). Over these depth ranges the biogenic sediments are characterized by a random arrangement of microfossils and display little chemical diagenetic alteration. The microfossils are dispersed within a fine-grained matrix that is predominantly microcrystalline carbonate particles on the Owen Ridge and clay and organic matter on the Oman margin. Sediments with abundant siliceous microfossils display distinct, open fabrics with high porosity. Porosity reduction resulting from gravitational compaction appears to be the primary process affecting fabric change in the biogenic sediment sections. Fabric of illite-rich clayey silts and silty claystones from the Indus Fan (Site 720) and Owen Ridge (Sites 722 and 731) was examined for a composite section extending from 45 to $985 \mathrm{mbsf}$. In this section fabric of the fine-grained turbidites changes from one with small flocculated clay domains, random particle arrangement, and high porosity to a fabric with larger domains, strong preferred particle orientation roughly parallel to bedding, and lower porosity. These changes are accomplished by a growth in domain size, primarily through increasing face-to-face contacts, and by particle reorientation which is characterized by a sharp increase in alignment with bedding between 200 and $400 \mathrm{mbsf}$. Despite extensive particle reorientation, flocculated clay fabric persists in the deepest samples examined, particularly adjacent to silt grains, and the sediments lack fissility. Fabric changes over the $45-985$ mbsf interval occur in response to gravitational compaction. Porosity reduction and development of preferred particle orientation in the Indus Fan and Owen Ridge sections occur at greater depths than outlined in previous fabric models for terrigenous sediments as a consequence of a greater abundance of silt and a greater abundance of illite and chlorite clays.
\end{abstract}

\section{INTRODUCTION}

Ocean Drilling Program Leg 117 drilled 12 sites in the western Arabian Sea at locations on the Indus Fan, Owen Ridge, and Oman margin (Fig. 1). The sediments recovered range from fine-grained terrigenous turbidites associated with the Indus Fan to pelagic carbonate sequences of varying composition. The objective of this paper is to describe fabric changes that accompany burial of the terrigenous and biogenic sediments. Sediment fabric of undisturbed samples was examined by scanning electron microscope (SEM) techniques. Grain size and clay mineralogy of the fabric samples were determined and, along with existing calcium carbonate and organic carbon concentration data, were used to identify the influence of sediment composition and grain size on fabric.

The fabrics of terrigenous and calcareous sediments are dissimilar, and changes that occur with burial are controlled by different factors. Factors influencing the fabric of fine-grained terrigenous sediments have been described in an extensive review by Bennett et al. (1977), and more recently by Bennett et al. (1988). These studies have shown that the fabric of clay-rich sediments is controlled by sediment composition, physicochemical conditions during and after deposition, and characteristics of the depositional processes. Clay-rich sediments in marine environments are typically deposited as flocculated or aggregated units of domains interconnected in edge-to-face, edge-to-edge, or face-to-face arrangements. With burial, mechanical compac-

\footnotetext{
${ }^{1}$ Prell, W. J., Niitsuma, N., et al., 1991. Proc. ODP, Sci. Results, 117: College Station, TX (Ocean Drilling Program).

2 Department of Geology and Geophysics, University of New Orleans, New Orleans, LA 70148, U.S.A.
}

tion alters fabric and reduces porosity through dewatering and particle reorientation. Effects of mechanical compaction are typically limited to the upper $500-1000 \mathrm{~m}$ of sedimentary sections (Bowles et al., 1969; Heling, 1970). At greater depths grain deformation, fracture or creep, and chemical diagenesis are responsible for fabric change and porosity reduction (Meade, 1966; Bowles et al., 1969; Bennett et al., 1977; Bryant et al., 1981). Studies of burial transformations in carbonate sediments have focused on chemical diagenesis and identifying the stage at which it replaces mechanical compaction as the dominant diagenetic process. Burial diagenesis of pelagic carbonate sediments has been studied at a number of Deep Sea Drilling Project (DSDP) sites and reviewed by Garrison (1981). Garrison (1981) concluded that the transformation from ooze to chalk to limestone is not a function of burial depth and age, but rather, as proposed earlier by Schlanger and Douglas (1974), a combination of effects of variations in sedimentation rate, water depth, biological productivity, temperature, calcium carbonate concentration, and original composition of the calcareous ooze.

Sedimentary sections from five sites drilled during Leg 117 were selected for examining burial transformation of sediment fabric. The fabric of terrigenous sediments was studied for finegrained turbidite sequences recovered on the Indus Fan (Site 720) and Owen Ridge (Sites 722 and 731). Fabric of biogenic sediments was examined for the nannofossil and marly nannofossil oozes and chalks recovered on the Owen Ridge (Site 722) and Oman margin (Sites 723 and 728).

\section{SITE DESCRIPTIONS}

\section{Site 720}

Site 720 is located on the western edge of the Indus Fan at a water depth of $4045 \mathrm{~m}$ (Fig. 1), near the boundary between the 


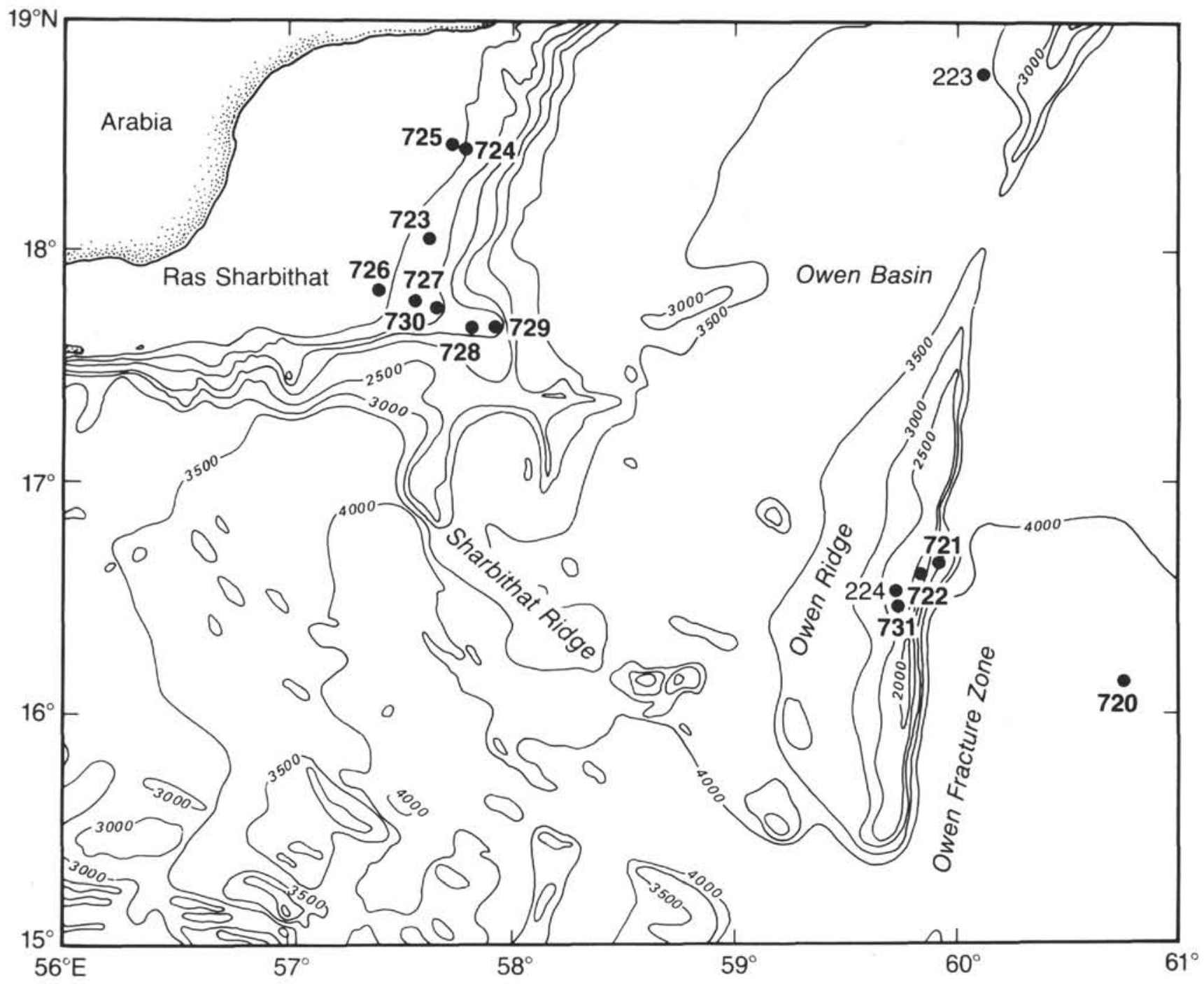

Figure 1. Bathymetric map of the western Arabian Sea showing the location of Leg 117 sites (Sites 720-731).

middle and lower fan (Kolla and Coumes, 1987). It is approximately $5 \mathrm{~km}$ east of a meandering channel at a location selected to avoid channel sand deposits (Prell, Niitsuma, et al., 1989). A 414.3-m-thick, Pleistocene to Holocene section of turbiditic clastics interbedded with nannofossil ooze was recovered at Site 720 .

Sediments at Site 720 were divided into two lithologic units (Table 1). Lithologic Unit I (0-17.2 mbsf, Holocene to upper Pleistocene) is a relatively uniform interval of nannofossil ooze that was deposited following the abandonment of the major turbidity current channel on the Indus Fan. Lithologic Unit II (17.2-414.3 mbsf, Pleistocene) consists of a heterogeneous mixture of terrigenous turbidite sequences with minor occurrences of nannofossil ooze. Unit II contains three distinct facies: (1) calcareous facies of nannofossil ooze and associated muds and clays; (2) thin- to thick-bedded facies of fine- and coarse-grained turbidites; and (3) thick-bedded facies of fine- and coarse-grained turbidites. The calcareous facies is similar to Unit I in composition and inferred depositional conditions. The thin- to thickbedded facies and thick-bedded facies are characterized by fining-upward sequences with sharp lower contacts, uniform bases of silt or sand, and gradational fine-grained tops. The two facies are distinguished by the occurrence of coarse-grained bases more than $5 \mathrm{~cm}$ thick in the thick-bedded facies. Sedimentation rates within the turbidite sequence average more than a factor- of-ten higher than the pelagic deposits (Table 1). The porosity of sediments of Unit I is nearly constant at $70 \%$, whereas in Unit II porosity decreases gradually downsection from $60 \%$ to $46 \%$ (Fig. 2). Average grain density in Units I and II ranges from 2.65 to $2.75 \mathrm{~g} / \mathrm{cm}^{3}$.

\section{Site 722}

Site 722 is located on the crest of the Owen Ridge at a water depth of $2028 \mathrm{~m}$ (Fig. 1). A 565.6-m section ranging from Holocene to early Miocene in age was recovered at this site. The lower portion of the section predates uplift of the ridge and consists of terrigenous turbidite sequences deposited on the Indus Fan. Following uplift of the ridge, initiated during early Miocene time, the site has been above the reach of turbidite deposition and has accumulated primarily pelagic, carbonate-rich sediments, deposited under the influence of upwelling induced by the Indian Ocean Southwest Monsoon. Site 722 presently is at a water depth shallower than the Holocene lysocline, 3900-4000 m (Kolla et al., 1976), and late Neogene age sediments are characterized by good carbonate preservation. The pelagic section at Site 722 was selected for fabric study because it is thicker and more complete than comparable sections drilled at other Owen Ridge sites (Sites 721 and 731). 
Table 1. Lithologic summaries for Sites 720, 722, 723, 728, and 731.

\begin{tabular}{|c|c|c|c|c|c|}
\hline Site & $\begin{array}{l}\text { Lithologic } \\
\text { Unit }\end{array}$ & $\begin{array}{l}\text { Depth } \\
\text { (mbsf) }\end{array}$ & Age & Lithology & $\begin{array}{l}\text { Sedimentation } \\
\text { rate }(\mathrm{m} / \mathrm{m} . \mathrm{y} .)\end{array}$ \\
\hline \multirow[t]{2}{*}{720} & I & $0-17.2$ & $\begin{array}{l}\text { Holocene- } \\
\text { late Pleistocene }\end{array}$ & $\begin{array}{l}\text { Nannofossil and foraminifer-bearing nanno- } \\
\text { fossil oozes }\end{array}$ & 32 \\
\hline & II & $17.2-414.3$ & Pleistocene & Silty clay, silt, sand, minor nannofossil ooze & $137-944$ \\
\hline \multirow[t]{4}{*}{722} & I & $0-221.5$ & $\begin{array}{l}\text { Holocene- } \\
\text { late Miocene }\end{array}$ & $\begin{array}{l}\text { Foraminifer-bearing nannofossil ooze, nan- } \\
\text { nofossil and marly nannofossil oozes/ } \\
\text { chalks; alternating light and dark beds }\end{array}$ & $17-45$ \\
\hline & II & $221.5-343.4$ & middle Miocene & $\begin{array}{l}\text { Nannofossil, foraminifer-bearing nannofos- } \\
\text { sil, diatom-nannofossil, radiolarian- } \\
\text { bearing nannofossil, and diatom-marly } \\
\text { nannofossil chalks; alternating light and } \\
\text { dark beds }\end{array}$ & $15-54$ \\
\hline & III & $343.4-411.1$ & middle Miocene & $\begin{array}{l}\text { Nannofossil, foraminifer-bearing nannofos- } \\
\text { sil, and marly nannofossil chalks; alter- } \\
\text { nating light and dark beds }\end{array}$ & $8-15$ \\
\hline & IV & 411.1-565.6 & $\begin{array}{l}\text { middle Miocene- } \\
\text { early Miocene }\end{array}$ & $\begin{array}{l}\text { Interbedded fine-grained turbidites and } \\
\text { marly nannofossil chalk }\end{array}$ & ${ }^{\mathrm{b}} \mathrm{ND}$ \\
\hline 723 & I & $0-432.3$ & $\begin{array}{l}\text { Holocene- } \\
\quad \text { late Pliocene }\end{array}$ & $\begin{array}{l}\text { Foraminifer-bearing marly nannofossil ooze, } \\
\text { calcareous clayey silt, dolomitic lime- } \\
\text { stone, laminated diatom ooze/diatomite }\end{array}$ & $150-240$ \\
\hline \multirow[t]{3}{*}{728} & IA & $0-58$ & $\begin{array}{l}\text { Holocene- } \\
\text { early Pleistocene }\end{array}$ & $\begin{array}{l}\text { Foraminifer-nannofossil, foraminifer-bear- } \\
\text { ing, and marly nannofossil oozes; alter- } \\
\text { nating light and dark beds }\end{array}$ & $25-65$ \\
\hline & IB & $58-320$ & $\begin{array}{l}\text { early Pleistocene- } \\
\text { late Miocene }\end{array}$ & $\begin{array}{l}\text { Foraminifer-bearing marly nannofossil } \\
\text { oozes/chalks; alternating light and dark } \\
\text { beds }\end{array}$ & $11-87$ \\
\hline & IC & $320-347.7$ & late Miocene & $\begin{array}{l}\text { Diatom-bearing nannofossil, marly nanno- } \\
\text { fossil, and nannofossil chalks; alternat- } \\
\text { ing light and dark beds }\end{array}$ & 28 \\
\hline \multirow[t]{5}{*}{731} & IA & $0-66.3$ & $\begin{array}{l}\text { Holocene- } \\
\text { Pleistocene }\end{array}$ & $\begin{array}{l}\text { Nannofossil, marly nannofossil, foramini- } \\
\text { fer-bearing nannofossil, and diatoma- } \\
\text { ceous nannofossil oozes; alternating } \\
\text { light and dark beds }\end{array}$ & $34-69$ \\
\hline & IB & $66.3-146.5$ & $\begin{array}{l}\text { early Pleistocene- } \\
\text { late Miocene }\end{array}$ & $\begin{array}{l}\text { Nannofossil and marly nannofossil oozes; } \\
\text { alternating light and dark beds }\end{array}$ & $20-44$ \\
\hline & II & $146.5-240.9$ & $\begin{array}{l}\text { late Miocene- } \\
\text { middle Miocene }\end{array}$ & $\begin{array}{l}\text { Nannofossil, marly nannofossil, and diato- } \\
\text { maceous marly nannofossil oozes/ } \\
\text { chalks, nannofossil-rich diatomaceous } \\
\text { mud/mudstone; alternating light and } \\
\text { dark beds }\end{array}$ & $20-36$ \\
\hline & III & $240.9-320.1$ & middle Miocene & $\begin{array}{l}\text { Nannofossil and marly nannofossil chalks } \\
\text { alternating light and dark beds }\end{array}$ & $9-20$ \\
\hline & IV & $320.1-994.2$ & $\begin{array}{l}\text { middle Miocene- } \\
\text { late Oligocene(?) }\end{array}$ & $\begin{array}{l}\text { Interbedded siltstones to nannofossil chalk, } \\
\text { mud turbidites, sand turbidites }\end{array}$ & ${ }^{\mathrm{b}} \mathrm{ND}$ \\
\hline
\end{tabular}

a Summaries based on lithologic-unit descriptions contained in Prell, Niitsuma, et al. (1989).

b No data (ND), poor age control prevents estimation of sedimentation rates.

Four lithologic units were recognized at Site 722 (Table 1). Lithologic Unit I (0-221.5 mbsf, Holocene to upper Miocene) consists of alternating light and dark beds of nannofossil and marly nannofossil ooze/chalk. Dark beds are characterized by higher clay and organic carbon content and lower calcium carbonate content than light beds. In Unit I calcium carbonate and organic carbon concentrations range from $50 \%$ to $89 \%$ and $0.2 \%$ to $3.0 \%$, respectively. Lithologic Unit II (221.5-343.4 mbsf, upper to middle Miocene) differs from Unit I in that it contains a greater abundance of siliceous microfossils. Siliceous microfossils increase in abundance from trace amounts at the bottom of Unit I to a maximum of $20 \%$ between 245 and 330 mbsf. Below $330 \mathrm{mbsf}$ the abundance of biogenic silica decreases sharply to trace amounts at the top of lithologic Unit III. Unit III (343.4-411.1 mbsf, middle Miocene) is primarily composed of white nannofossil chalk. Lithologic Unit IV (411.1-565.1 mbsf, middle to lower Miocene) is characterized by silty clay turbidites overlain by nannofossil chalk. The upper $87 \mathrm{~m}$ of Unit IV consists of fine-grained turbidite sequences (20-50 cm thick) capped by marly nannofossil chalk. Below 498 mbsf turbidites lack the chalk cap and are characterized by downsection coarsening of basal layers and fining of upper layers within individual sequences.
Transitions in the porosity profile at Site 722 (Fig. 3) mark the boundaries of the lithologic units. Porosity decreases gradually from $64 \%$ at the seafloor to $59 \%$ at the base of Unit I (Fig. 3). A porosity maximum between 90 and 110 mbsf corresponds to an increase in clay and organic carbon abundance. The biogenic-silica-rich Unit II displays anomalously high porosity with a maximum of $74 \%$. Porosity decreases rapidly from $65 \%$ to $45 \%$ in the upper $40 \mathrm{~m}$ of Unit III and is nearly constant in the lower portion of the unit. Unit IV is characterized by a uniform downsection decrease in porosity from $45 \%$ to $42 \%$. Grain density ranges between 2.55 and $2.75 \mathrm{~g} / \mathrm{cm}^{3}$ for Units I and III and between 2.60 and $2.80 \mathrm{~g} / \mathrm{cm}^{3}$ in Unit IV. In Unit II grain density varies inversely with the abundance of biogenic silica, reaching a minimum of $2.30 \mathrm{~g} / \mathrm{cm}^{3}$ at 316 mbsf.

\section{Site 731}

Site 731 is located just below the crest of the Owen Ridge at a water depth of $2366 \mathrm{~m}$ (Fig. 1). A 994-m-thick section, Holocene to early Miocene or late Oligocene in age, was drilled at Site 731 (Table 1). The sedimentary section at this site is similar to that at Site 722 ; however, at Site 731 the pelagic interval is condensed to $320 \mathrm{~m}$ thick and the turbidite section was more deeply penetrated. The pelagic section at Site 731 also differs in 


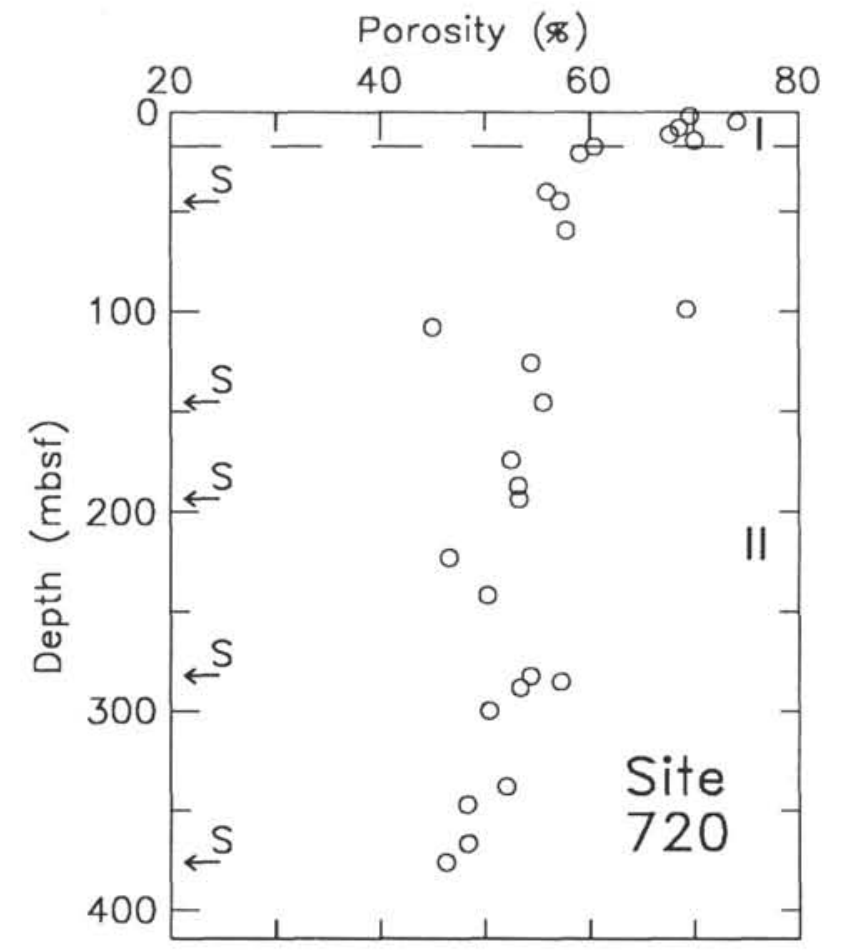

Figure 2. Porosity vs. depth at Site 720. Porosity values displayed in this profile and subsequent profiles were determined for discrete samples according to procedures described in Prell, Niitsuma, et al. (1989). On this profile and profiles that follow, depths of samples examined with the SEM are indicated by an arrow and S along the left side of the figure. Lithologic unit boundaries are indicated by horizontal dashed lines, and the units are labeled with Roman numerals along the right side of the figure.

that it is more siliceous rich in its upper part (Subunit IA, Table 1). The principal focus of fabric study at Site 731 was the thick turbidite section.

The turbidite sequence at Site 731 is contained within lithologic Unit IV (320.1-994.2 mbsf, middle Miocene to lower Miocene-upper Oligocene). Relative abundances of biogenic carbonate, coarse detrital components, and fine-grained detrital components were used to distinguish three facies within this unit: (1) mixed turbidite-carbonate facies; (2) mud turbidite facies; and (3) coarse-grained turbidite facies. The mixed turbidite-carbonate facies is present in the top $40 \mathrm{~m}$ of Unit IV and consists of fine-grained turbidites capped by chalk. The mud turbidite facies occurs below $360 \mathrm{mbsf}$ and is characterized by fining-upward beds, 3-30 cm thick, with sharp bases and basal layers of parallel laminated siltstone or clayey siltstone that grade upward to uniform silty claystone. Quartz, clay, and inorganic calcite are the dominant constituents of this facies. The coarse-grained turbidite facies is characterized by sandy siltstones to sandstones, $10-150 \mathrm{~cm}$ thick, that occur as either coarse-grained bases of fining-upward sequences which extend into a siltstone or thin silty claystone cap, or as discrete ungraded to slightly graded coarse-grained beds. The sandstones are commonly poorly cemented and friable; although, sandstones heavily cemented with calcite are present. The mud turbidite and coarse-grained turbidite facies are not depth restricted and are interbedded throughout the interval from 360 to 994 mbsf.

Porosity decreases relatively uniformly with increasing burial depth in Unit IV at Site 731 (Fig. 4). Variability in the profile

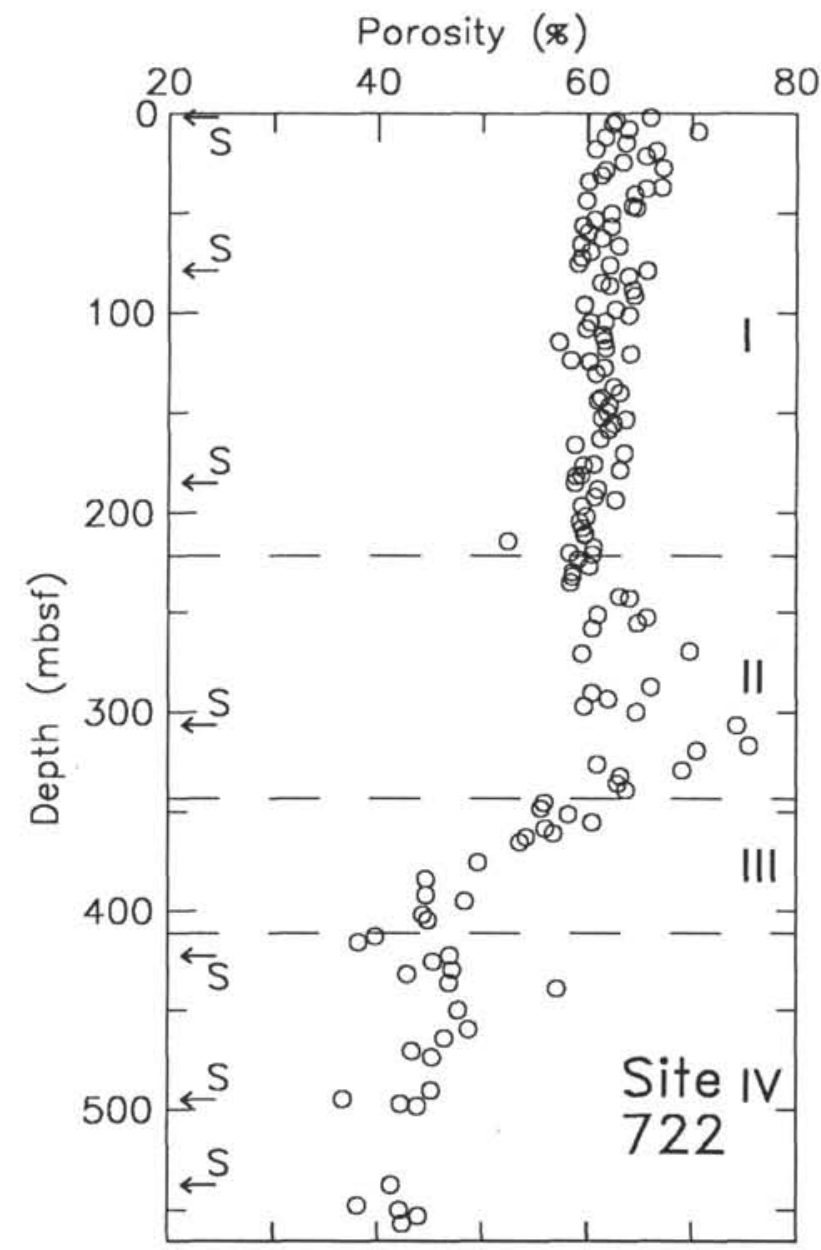

Figure 3. Porosity vs. depth at Site 722 .

primarily reflects differences in the porosity of the fine-grained and coarse-grained turbidites. Porosity of the mud turbidites and poorly cemented sandstones decreases downsection from $48 \%$ to $31 \%$ and $31 \%$ to $26 \%$, respectively. Porosity of the wellcemented sandstones was estimated to range from $2 \%$ to $8 \%$. Grain density averages $2.70 \mathrm{~g} / \mathrm{cm}^{3}$ and $2.69 \mathrm{~g} / \mathrm{cm}^{3}$ for the mud turbidites and sandstones, respectively.

Compressional-wave velocity was measured for all sections drilled during Leg 117; however, because of the deeper penetration at Site 731 , trends in velocity variation are more clearly evident. The pelagic section at Site 731 is marked by relatively little change in velocity above $240 \mathrm{mbsf}$ and a steady increase with depth in Unit III between 240 and 320 mbsf (Fig. 5A). The terrigenous turbidites of Unit IV show a relatively regular downsection increase in velocity with values measured perpendicular to bedding increasing from approximately 1600 to $2200 \mathrm{~m} / \mathrm{s}$ (Fig. 5A). The profile of velocity anisotropy, the ratio of the difference of horizontal and vertical velocities to the mean velocity, expressed as a percentage (Carlson and Christensen, 1979), is shown in Figure 5B. Determination of velocity anisotropy for samples from depths less than 200 mbsf was not possible because the sediments were too soft or friable. Figure 5B shows that pelagic sediments of Units I through III are characterized by highly variable anisotropy with little evidence of a downsection trend. Fine-grained turbidites of Unit IV display a trend of increasing anisotropy with depth, characterized by moderate scatter (Fig. 5B). 


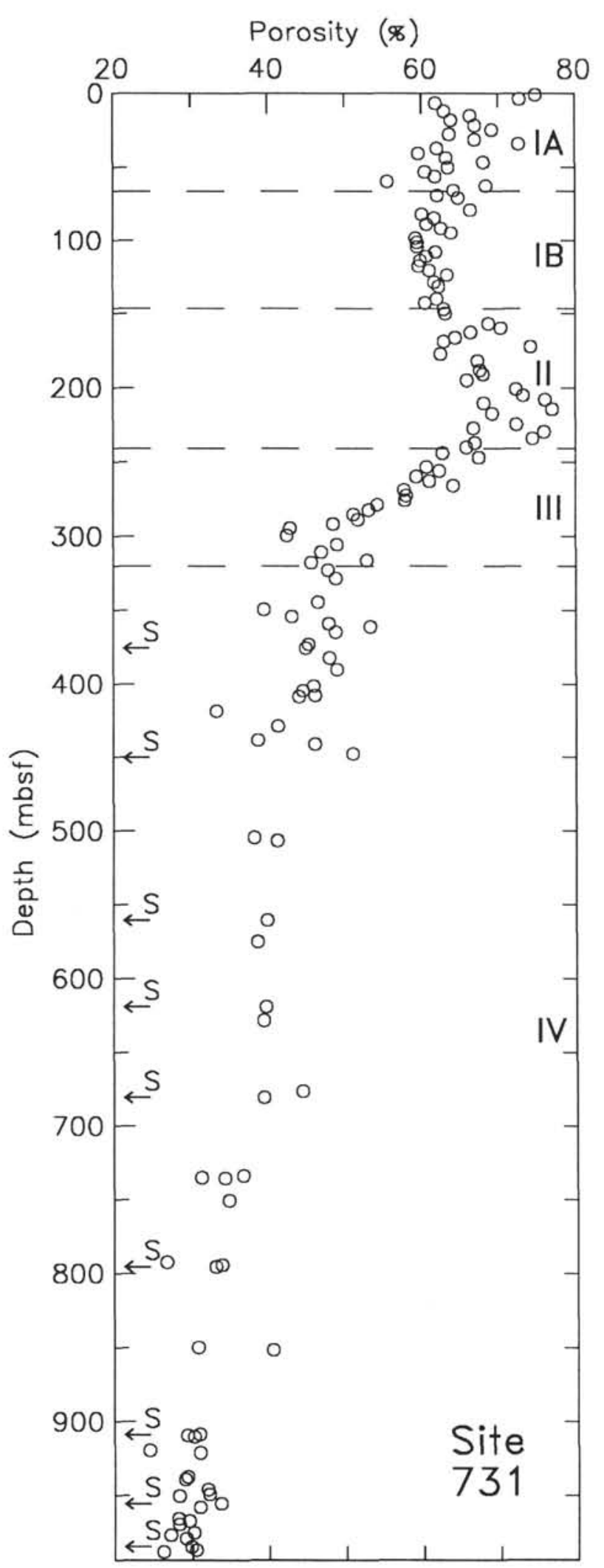

Figure 4. Porosity vs. depth at Site 731.

\section{Site 723}

Site 723 is located at a water depth of $808 \mathrm{~m}$ on the Oman continental margin (Fig. 1), near the center of an upper slope basin bounded by a ridge and fault block of presumed ophiolite basement. The site is presently located within the oxygen minimum zone (OMZ) which extends from 200 to $1200 \mathrm{~m}$ water depth and is characterized by $\mathrm{O}_{2}$ concentrations $<0.2 \mathrm{~mL} / \mathrm{L}$. A 429-m section, Holocene to late Pliocene in age, was recovered at Site 723. The sediments are organic-carbon rich, reflecting deposition associated with the combined effects of monsoon-induced upwelling and the OMZ.

One lithologic unit was identified at Site 723 (Table 1), within which one major facies (Facies I) and two minor facies (Facies II and III) were distinguished. Facies I consists of foraminiferbearing marly nannofossil ooze and calcareous clayey silt and is characterized by biogenic carbonate contents between $30 \%$ and $80 \%$ and terrigenous components (clay and silt-size detrital carbonate) that vary in abundance from $30 \%$ to $80 \%$. The organic carbon content is high, ranging from $0.7 \%$ to $6.8 \%$. The minor facies, Facies II and III, occur intermittently below $240 \mathrm{mbsf}$. Facies II consists of thin cemented layers of dolomitic limestone that, based on log data, may be up to $1 \mathrm{~m}$ thick. Light and dark laminae of diatom ooze and marly nannofossil ooze, 0.1-1.0 mm thick, comprise Facies III.

The porosity profile for Site 723 (Fig. 6) displays large variations as a consequence of varying abundance of organic matter and siliceous microfossils. Porosity increases with increasing abundance of both of these components. The profile is characterized by considerable scatter with a general decrease in porosity from approximately $66 \%$ at the seafloor to $56 \%$ at $195 \mathrm{mbsf}$. Below 195 mbsf porosity is nearly constant at $56 \%$ between 195 and 270 mbsf, increases from $56 \%$ to $62 \%$ between 270 and 340 mbsf, and increases from $56 \%$ to $63 \%$ between 360 and 410 mbsf. Grain density ranges from 2.20 to $2.65 \mathrm{~g} / \mathrm{cm}^{3}$, and varies inversely with the abundance of organic matter and biogenic silica.

\section{Site 728}

Site 728 is located on the Oman margin at a water depth of $1428 \mathrm{~m}$ (Fig. 1), near the center of a distal slope basin formed by a narrow half-graben in ophiolitic basement. Benthic foraminifers indicate that the site has experienced rapid vertical movement from upper bathyal depths in the late Miocene, rising to neritic depths $(<150 \mathrm{~m})$ in the early Pliocene, and subsiding to upper middle bathyal depths $(>500 \mathrm{~m})$ in the late Pliocene to Pleistocene. Site 728 is located near the lower boundary of the $\mathrm{OMZ}$, and a zone of high organic carbon concentrations that is present between 80 and 110 mbsf is thought to reflect movement of the site through the OMZ in the late Pliocene. The $348-\mathrm{m}$ thick sedimentary section drilled at Site 728 is more pelagic than the section at Site 723 , the ratio of biogenic to terrigenous sediment is higher, but it still reflects the proximal effects of monsoonal upwelling.

One lithologic unit, divided into three subunits, was identified at Site 728 (Table 1). Subunit IA (0-58 mbsf, Holocene to lower Pleistocene) consists of nannofossil and marly nannofossil oozes with abundant foraminifers $(>10 \%$ in the upper 20 $\mathrm{m})$. The terrigenous sediment component is dominated by clay $(10 \%-35 \%)$ and silt- and clay-sized detrital calcite $(10 \%-40 \%)$. Calcium carbonate content varies between $50 \%$ and $65 \%$, and organic carbon concentration ranges from $0.7 \%$ to $2.4 \%$. Subunit IB (58-320 mbsf, lower Pleistocene to upper Miocene) grades downward from a foraminifer-bearing marly nannofossil ooze to marly nannofossil and nannofossil ooze. Siliceous microfossils are present throughout this unit with well-preserved radiolarians common below 85 mbsf. The interval between 80 and 


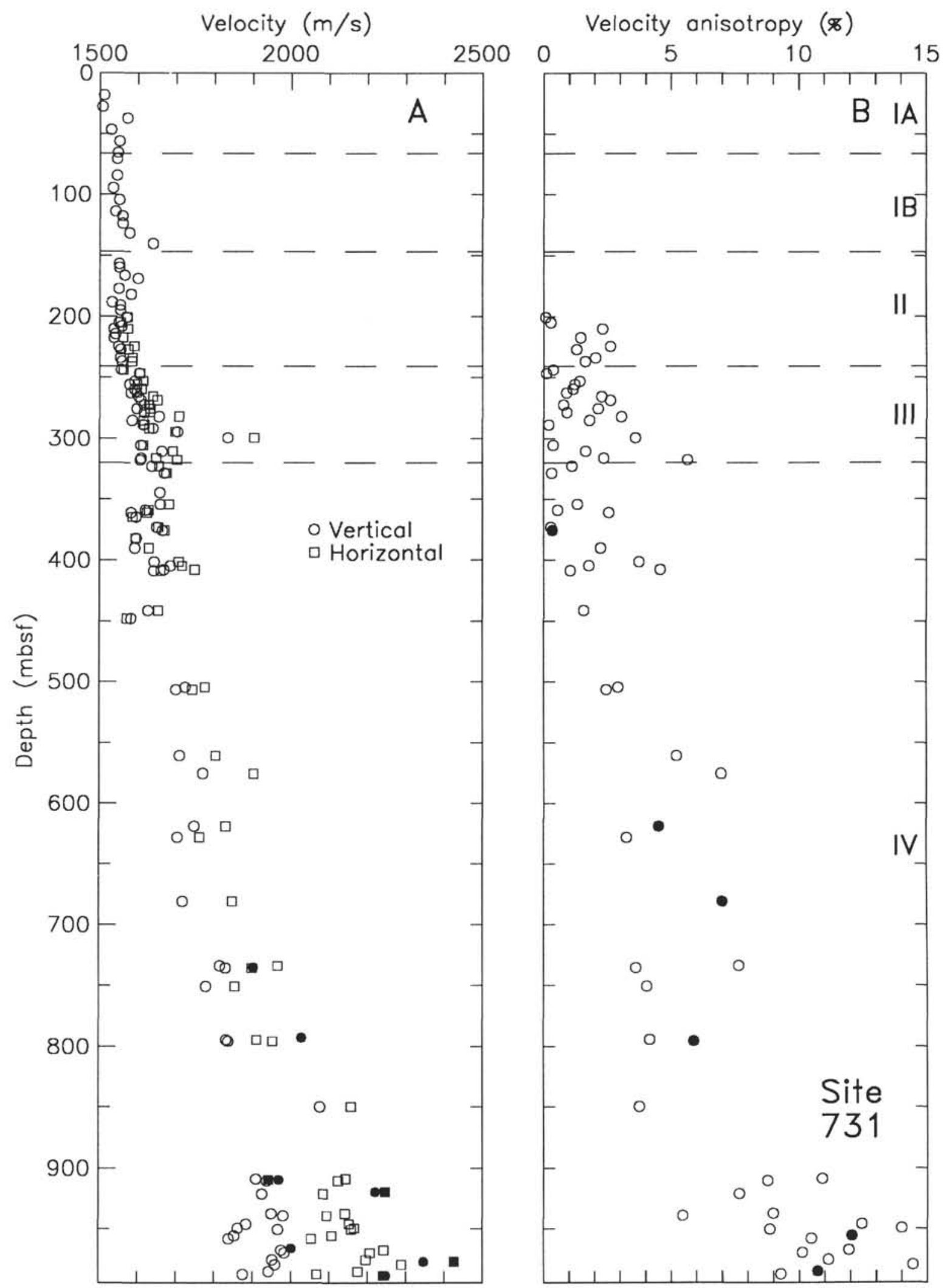

Figure 5. A. Compressional-wave velocity vs. depth at Site 731. Vertical and horizontal velocities for poorly cemented silty sandstones are shown as solid circles and solid squares, respectively. Values for well-cemented sandstones range from 3800 to $4700 \mathrm{~m} /$ $\mathrm{s}$ and are not shown. Velocities were determined for discrete samples using a Hamilton Frame Velocimeter according to procedures described in Prell, Niitsuma, et al. (1989). B. Velocity anisotropy vs. depth at Site 731. Only values for fine-grained turbidites are shown for Unit IV. Solid circles represent samples for which particle orientation was measured (see Fig. 15). 


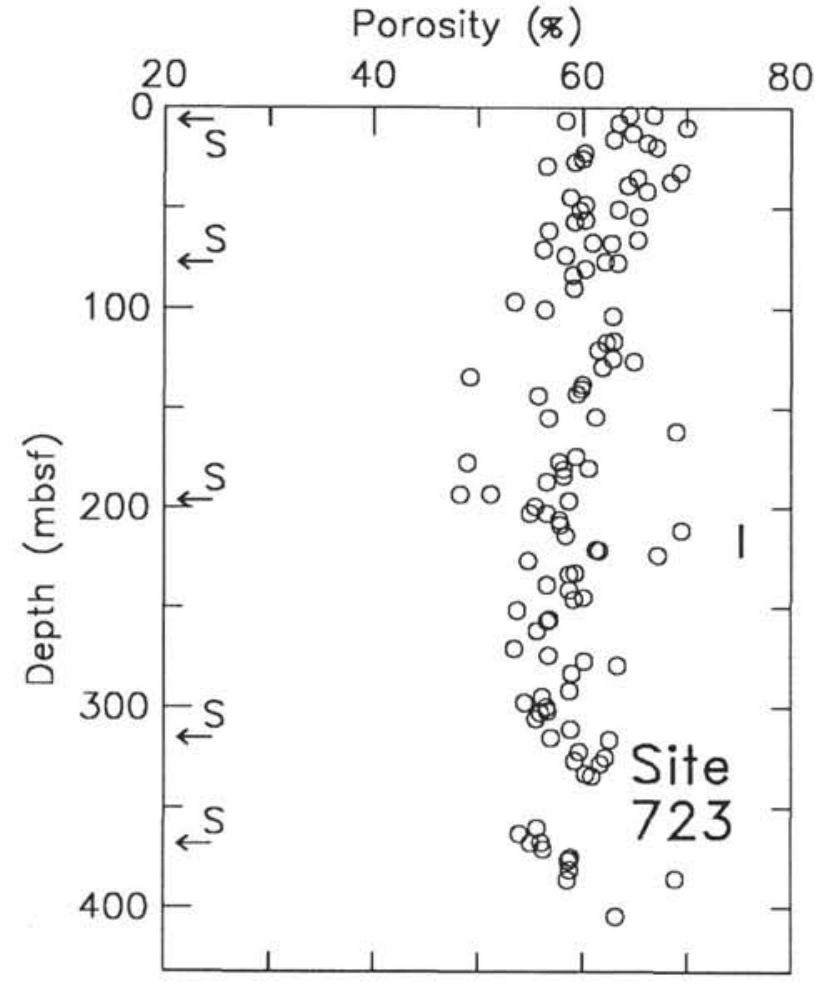

Figure 6. Porosity vs. depth at Site 723.

$110 \mathrm{mbsf}$ is characterized by high organic carbon concentrations (up to $5.3 \%$ ). Downsection the organic carbon concentration gradually decreases but remains high, ranging from $1.0 \%$ to $3.8 \%$. With increasing depth in Subunit IB the abundance of light-colored, nannofossil-rich beds increases and calcium carbonate concentration increases, with values up to $72 \%$. Subunit IC (320-347.7 mbsf, upper Miocene) is distinguished from the lower part of Subunit IB by a greater abundance of siliceous microfossils. The siliceous assemblage is composed primarily of diatoms, which range in abundance from $10 \%$ to $35 \%$.

Porosity variation at Site 728 , as at Site 723 , reflects changes in the abundance of organic matter and siliceous microfossils. From the seafloor to the base of Subunit IA ( $58 \mathrm{mbsf}$ ) porosity decreases from $64 \%$ to $55 \%$ (Fig. 7). In Subunit IB porosity increases with depth as organic carbon concentration and radiolarian abundance increase. A broad porosity maximum with values up to $67 \%$ extends from 80 mbsf to approximately 150 mbsf. Below 150 mbsf porosity gradually decreases to $58 \%$ at the base of Subunit IB. Porosity again increases, up to $65 \%$, in Subunit IC as the abundance of siliceous microfossils increases. As at Site 723 , grain density varies inversely with organic carbon and biogenic silica concentrations at Site 728. Average grain density is slightly higher at Site 728 than at Site 723 , ranging from 2.40 to $2.75 \mathrm{~g} / \mathrm{cm}^{3}$, and reflects the lower organic carbon concentration and higher calcium carbonate concentration.

\section{METHODS}

Samples for fabric analysis were obtained on board the JOIDES Resolution immediately after core sections were split. Unconsolidated core intervals were sampled by pushing a polystyrene "paleomag" cube $(2 \times 2 \times 1.5 \mathrm{~cm})$ into the soft sediment in such a way as to minimize sample disturbance. Samples from lithified sediments were cut out with a double-bladed rock saw and placed into the cubes. Sample cubes were marked for bedding orientation, sealed to be airtight, and stored at $4^{\circ} \mathrm{C}$. Care

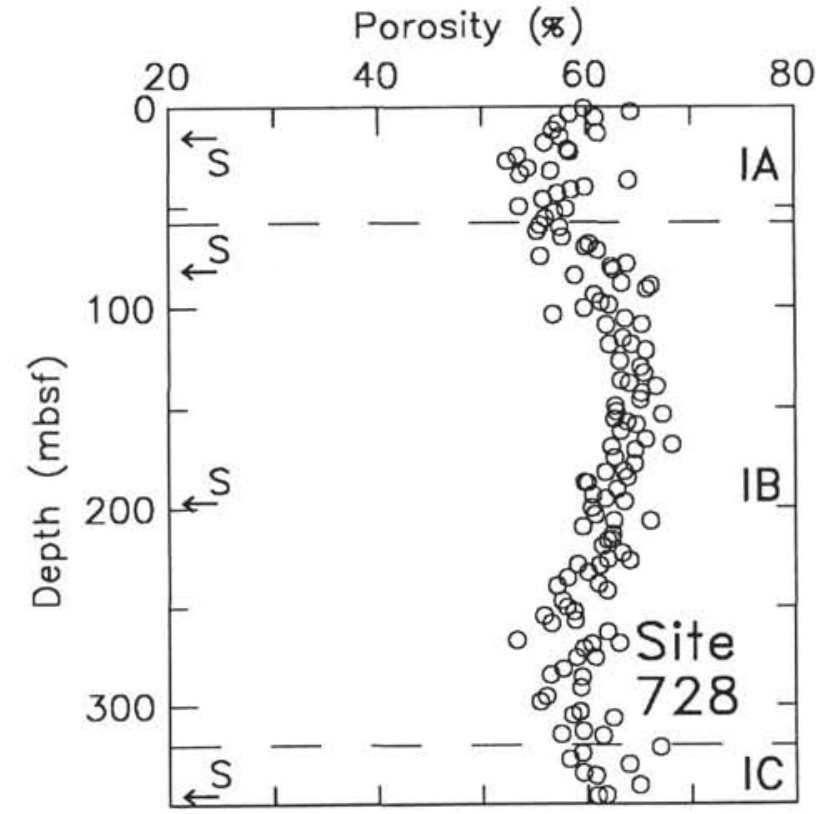

Figure 7. Porosity vs. depth at Site 728.

was taken to maintain saturation to minimize disruption of the in situ fabric by shrinkage or distortion of clay particles. Samples were extracted from the polystyrene cubes using a rotary (dremel) tool equipped with a small circular blade. Samples were cut approximately in half using a fine wire, razor blade, or the dremel tool, depending on the sediment consistency. Extreme care was taken to minimize disturbance while extracting and cutting samples. During the extraction and subsequent processing, identification of bedding orientation was maintained.

Samples were prepared for SEM examination using procedures developed by Bennett et al. (1977). These techniques include replacement of interstitial fluids, critical-point drying, and electrostatic cleaning. Replacement of the original interstitial brines of the samples, a preparatory step for critical-point drying, consisted of soaking the samples in a series of solutions of ethanol and salt water, ethanol, ethanol and amyl acetate, and amyl acetate. Samples were dried by critical-point drying to avoid distortion of sediment fabric caused by surface tension during air drying. Dried samples were mounted on SEM stubs with bedding generally perpendicular to the surface of the stubs. The samples were fractured with a razor blade to obtain a fresh surface, which was subsequently cleaned of loose particles using the electrostatic technique of Hulbert and Bennett (1975). Immediately after electrostatic cleaning the samples were coated, first with carbon and then gold. Sequential coating with carbon and gold minimized the excessive charging that characterized samples coated only with gold.

Particle orientation was quantified for selected samples using enlarged SEM photomicrographs and a modified point-count technique. Photomicrographs used for the analysis were of approximately equivalent magnification. Transparent overlays were placed over the photographs, and lines scaled to be separated by $1 \mu \mathrm{m}$ (relative to the sample surface) were drawn on the overlays. Particles crossing the overlay lines were marked with a line along the particle's bright edge or tangent to the particle's long axis in the case of microfossils or silt grains. The angles between the overlay lines and those marking particles were measured between $0^{\circ}$ and $180^{\circ}$. An average of 300 particle orientations were measured on each photograph. Duplicate analyses were performed for each of the selected samples using two different photomicrographs. 
Grain size (sand, silt, and clay percentages) and clay mineralogy were determined for samples taken adjacent to the fabric samples for purposes of shipboard porosity and bulk density measurements. These samples were initially treated with concentrated, $\mathrm{pH}$-neutralized hydrogen peroxide to disaggregate the sediment and remove organic matter. After the hydrogen peroxide treatment the sediment was soaked in a sodium hexametaphosphate dispersant solution and subsequently wet-sieved with a $62-\mu \mathrm{m}$ sieve to isolate the sand fraction. Silt-and clay-sized particles were separated by centrifugation, using $4 \mu \mathrm{m}$ as the boundary between silt and clay. Speed and duration of centrifugation were determined using a modified version of Stokes Law (Müller, 1967). Clay mineralogy was determined for particles less than $2 \mu \mathrm{m}$ diameter. Particles in this size range were separated by centrifugation from the clay fraction and treated with a solution of $25 \%$ acetic acid to remove calcite. Samples were shaken for $2 \mathrm{hr}$ to facilitate calcite dissolution, and the acid solution was subsequently drawn off and replaced with sodium hexametaphosphate solution to disperse the clays. Mineralogy of the $<2-\mu \mathrm{m}$ fraction was determined by X-ray diffraction using oriented clay-particle mounts. Semi-quantitative abundances of clay minerals were obtained using diffractograms for glycolated samples and the procedure of Biscaye (1965). Biscaye's method was modified by using the techniques of Kolla et al. (1981) to estimate the abundance of palygorskite.

\section{RESULTS}

Sediments of the Indus Fan, Owen Ridge, and Oman margin examined for variations in sediment fabric can be divided into two broad groups: (1) biogenic sediments, the various types of nannofossil and marly nannofossil ooze/chalk and (2) terrigenous turbidites. These two categories of sediments are characterized by dissimilar fabrics and distinct differences in texture and composition, summarized in Tables 2 and 3, respectively.
Sampling of biogenic sediments was biased toward the more clay-rich intervals of marly nannofossil oozes. Terrigenous-sediment fabric samples primarily came from clay-rich intervals of turbidite sequences.

\section{Biogenic Sediments}

Grain-size of the biogenic sediment samples from Sites 722 , 723 , and 728 varies with the microfossil assemblage. Near-surface samples from the three sites are enriched in foraminifers and contain $11 \%-16 \%$ sand. Samples from the deeper parts of the sections at the three sites are finer grained, with the exception of a sample from the siliceous-microfossil-rich Unit II at Site 722 , which has a sand content of $14 \%$. The biogenic sediments display a progressive offshore fining. Samples from the upper slope of the Oman margin at Site 723 are $47 \%-64 \%$ silt and $24 \%-47 \%$ clay, whereas samples from the Owen Ridge at Site 722 are $26 \%-51 \%$ silt and $40 \%-69 \%$ clay (Table 2).

The biogenic sediment samples from the Owen Ridge and Oman margin contain a distinctive and uniform suite of clay minerals. Illite and palygorskite are the most abundant clay minerals, with concentrations ranging from $26 \%$ to $49 \%$ and $23 \%$ to $52 \%$, respectively (Table 3 ). Concentration ranges for the other clay minerals are $9 \%-39 \%$ for smectite/mixed layer clays, $0 \%-9 \%$ for chlorite, and $0 \%-5 \%$ for kaolinite.

Organic carbon concentration is moderately high in the biogenic sediments. Concentrations are highest in samples from the Oman margin, Sites 723 and 728 , with a general range of $0.5 \%$ $6.0 \%$ (Table 3). Organic carbon content in biogenic sediment samples from the Owen Ridge is lower, ranging from $<0.5 \%$ to $2.5 \%$. Calcium carbonate concentration within the biogenic sediments ranges from $31 \%$ to $69 \%$ (Table 3 ).

The fabric of biogenic sediments from near the seafloor is characterized by a loose packing of randomly arranged microfossils. At Site 722 the sample at 2 mbsf displays a porous fabric

Table 2. Physical properties and grain size of fabric samples.

\begin{tabular}{|c|c|c|c|c|c|c|c|}
\hline $\begin{array}{l}\text { Core, sample, } \\
\text { interval }(\mathrm{cm})\end{array}$ & $\begin{array}{l}\text { Depth } \\
\text { (mbsf) }\end{array}$ & $\begin{array}{l}\text { Sediment } \\
\text { type }\end{array}$ & $\begin{array}{c}\text { Porosity } \\
\%\end{array}$ & $\begin{array}{l}\text { Grain } \\
\text { density } \\
\mathrm{g} / \mathrm{cm}^{3}\end{array}$ & $\begin{array}{c}\text { Sand } \\
\%\end{array}$ & $\begin{array}{l}\text { Silt } \\
\%\end{array}$ & $\begin{array}{c}\text { Clay } \\
\%\end{array}$ \\
\hline $720 A-5 X-5,87-89$ & 45.07 & Ter & 57 & 2.80 & 0 & 54 & 46 \\
\hline $720 A-16 X-1,62-64$ & 145.32 & Bio & 56 & 2.60 & 2 & 43 & 55 \\
\hline $720 A-21 X-1,49-51$ & 193.49 & Ter & 53 & 2.71 & 2 & 51 & 47 \\
\hline $720 A-30 X-2,116-118$ & 282.46 & Bio & 54 & 2.75 & 0 & 58 & 42 \\
\hline $720 \mathrm{~A}-40 \mathrm{X}-1,26-28$ & 376.16 & Ter & 46 & 2.78 & 1 & 58 & 41 \\
\hline $722 \mathrm{~A}-1 \mathrm{H}-2,50-52$ & 2.00 & Bio & 66 & 2.67 & 16 & 44 & 40 \\
\hline $722 \mathrm{~A}-9 \mathrm{H}-2,53-55$ & 78.73 & Bio & 66 & 2.55 & 3 & 51 & 46 \\
\hline $722 \mathrm{~A}-20 \mathrm{X}-2,35-37$ & 185.15 & Bio & 59 & 2.56 & 4 & 27 & 69 \\
\hline $722 \mathrm{~B}-33 \mathrm{X}-2,25-27$ & 306.45 & Bio & 74 & 2.55 & 14 & 26 & 60 \\
\hline $722 \mathrm{~B}-45 \mathrm{X}-2,25-27$ & 422.55 & Ter & 47 & 2.75 & 0 & 39 & 61 \\
\hline $722 \mathrm{~B}-52 \mathrm{X}-5,81-83$ & 495.01 & Ter & 37 & 2.72 & 0 & 51 & 49 \\
\hline 722B-57X-1, 74-76 & 537.34 & Ter & 41 & 2.78 & 0 & 71 & 29 \\
\hline $723 \mathrm{~A}-1 \mathrm{H}-5,53-55$ & 6.53 & Bio & 58 & 2.40 & 11 & 65 & 24 \\
\hline $723 \mathrm{~A}-9 \mathrm{H}-2,48-50$ & 77.38 & Bio & 63 & 2.43 & 9 & 59 & 32 \\
\hline $723 \mathrm{~A}-21 \mathrm{X}-4,55-57$ & 196.45 & Bio & 59 & 2.55 & 8 & 55 & 37 \\
\hline $723 A-33 X-6,56-58$ & 315.16 & Bio & 57 & 2.37 & 5 & 48 & 47 \\
\hline $723 \mathrm{~B}-39 \mathrm{X}-5,79-81$ & 368.39 & Bio & 56 & 2.64 & 9 & 59 & 35 \\
\hline $728 \mathrm{~A}-2 \mathrm{H}-4,82-84$ & 14.92 & Bio & 58 & 2.74 & 16 & 48 & 36 \\
\hline $728 \mathrm{~A}-9 \mathrm{H}-4,78-80$ & 81.38 & Bio & 63 & 2.60 & 4 & 55 & 41 \\
\hline $728 \mathrm{~A}-21 \mathrm{X}-4,70-72$ & 197.00 & Bio & 64 & 2.61 & 4 & 46 & 50 \\
\hline $728 \mathrm{~B}-37 \mathrm{X}-5,78-80$ & 344.88 & Bio & 62 & 2.57 & 3 & 37 & 60 \\
\hline $731 \mathrm{~A}-40 \mathrm{X}-4,80-82$ & 375.70 & Ter & 45 & 2.73 & 0 & 42 & 58 \\
\hline 731B-5X-1, 146-148 & 450.36 & Ter & 51 & 2.76 & 0 & 47 & 53 \\
\hline 731C-4R-1, 34-36 & 560.54 & Ter & 40 & 2.76 & 0 & 46 & 54 \\
\hline 731C-6R-1, 97-99 & 619.07 & Ter & 40 & 2.71 & 0 & 49 & 51 \\
\hline $731 \mathrm{C}-8 \mathrm{R}-4,34-36$ & 680.74 & Ter & 39 & 2.75 & 0 & 38 & 62 \\
\hline $731 \mathrm{C}-12 \mathrm{R}-3,93-95$ & 795.43 & Ter & 33 & 2.71 & 0 & 50 & 50 \\
\hline $731 \mathrm{C}-16 \mathrm{R}-2,1-3$ & 908.81 & Ter & 29 & 2.66 & 20 & 60 & 20 \\
\hline $731 \mathrm{C}-21 \mathrm{R}-1,15-17$ & 955.55 & Ter & 34 & 2.72 & 0 & 31 & 69 \\
\hline $731 \mathrm{C}-24 \mathrm{R}-1,46-48$ & 984.96 & Ter & 30 & 2.64 & 0 & 49 & 51 \\
\hline
\end{tabular}

Abbreviations: $\mathrm{Ter}=$ terrigenous sediments, Bio $=$ biogenic sediments. 
Table 3. Clay mineralogy and calcium carbonate and organic carbon contents of fabric samples.

\begin{tabular}{|c|c|c|c|c|c|c|c|c|c|}
\hline $\begin{array}{l}\text { Core, sample, } \\
\text { interval }(\mathrm{cm})\end{array}$ & $\begin{array}{l}\text { Depth } \\
\text { (mbsf) }\end{array}$ & $\begin{array}{l}\text { Sediment } \\
\text { type }\end{array}$ & $\underset{\%}{\mathrm{Sm}}$ & $\begin{array}{l}\text { Il } \\
\%\end{array}$ & $\begin{array}{l}\mathrm{Chl} \\
\%\end{array}$ & $\underset{\%}{\mathrm{Kao}}$ & $\begin{array}{l}\text { Ply } \\
\%\end{array}$ & $\underset{\%}{{ }^{\mathrm{a}} \mathrm{CaCO}_{3}}$ & $\begin{array}{c}{ }^{a} \mathrm{C} \text {-org } \\
\%\end{array}$ \\
\hline $720 A-5 X-5,87-89$ & 45.07 & Ter & 7 & 82 & 11 & 1 & 0 & 13 & $<0.5$ \\
\hline $720 A-16 X-1,62-64$ & 145.32 & Bio & 16 & 44 & 14 & 4 & 22 & 30 & $0.5-1.0$ \\
\hline $720 \mathrm{~A}-21 \mathrm{X}-1,49-51$ & 193.49 & Ter & 2 & 86 & 8 & 4 & 0 & 11 & $<0.5$ \\
\hline $720 \mathrm{~A}-30 \mathrm{X}-2,116-118$ & 282.46 & Bio & 27 & 37 & 10 & 3 & 23 & 34 & $0.5-1.0$ \\
\hline $720 \mathrm{~A}-40 \mathrm{X}-1,26-28$ & 376.16 & Ter & 12 & 69 & 13 & 5 & 0 & 13 & $<0.5$ \\
\hline $722 \mathrm{~A}-1 \mathrm{H}-2,50-52$ & 2.00 & Bio & 16 & 49 & 8 & 1 & 26 & 69 & $(<0.5)$ \\
\hline $722 \mathrm{~A}-9 \mathrm{H}-2,53-55$ & 78.73 & Bio & 19 & 39 & 9 & 1 & 31 & 50 & $(2.0-2.5)$ \\
\hline $722 \mathrm{~A}-20 \mathrm{X}-2,35-37$ & 185.15 & Bio & 39 & 30 & 6 & 2 & 23 & 89 & $(1.0-1.5)$ \\
\hline $722 \mathrm{~B}-33 \mathrm{X}-2,25-27$ & 306.45 & Bio & 14 & 34 & 0 & 0 & 52 & 25 & $(1.0-1.5)$ \\
\hline $722 \mathrm{~B}-45 \mathrm{X}-2,25-27$ & 422.55 & Ter & 12 & 64 & 23 & 1 & 0 & 5 & $(<0.5)$ \\
\hline $722 B-52 X-5,81-83$ & 495.01 & Ter & 20 & 59 & 18 & 2 & 0 & 10 & $(<0.5)$ \\
\hline 722B-57X-1, 74-76 & 537.34 & Ter & 8 & 54 & 30 & 8 & 0 & (10) & $(<0.5)$ \\
\hline $723 \mathrm{~A}-1 \mathrm{H}-5,53-55$ & 6.53 & Bio & 13 & 43 & 8 & 5 & 31 & (45) & $(2.0-2.5)$ \\
\hline $723 \mathrm{~A}-9 \mathrm{H}-2,48-50$ & 77.38 & Bio & 11 & 39 & 5 & 3 & 43 & 60 & $3.5-4.0$ \\
\hline $723 \mathrm{~A}-21 \mathrm{X}-4,55-57$ & 196.45 & Bio & 9 & 46 & 2 & 3 & 41 & 61 & $1.0-1.5$ \\
\hline $723 A-33 X-6,56-58$ & 315.16 & Bio & 15 & 43 & 3 & 2 & 38 & 64 & $5.5-6.0$ \\
\hline $723 B-39 X-5,79-81$ & 368.39 & Bio & 16 & 43 & 4 & 2 & 36 & $(50)$ & $(5.0-5.5)$ \\
\hline $728 \mathrm{~A}-2 \mathrm{H}-4,82-84$ & 14.92 & Bio & 10 & 46 & 7 & 2 & 36 & 64 & $(0.5-1.0)$ \\
\hline $728 \mathrm{~A}-9 \mathrm{H}-4,78-80$ & 81.38 & Bio & 15 & 43 & 5 & 3 & 43 & 49 & $4.5-5.0$ \\
\hline $728 \mathrm{~A}-21 \mathrm{X}-4,70-72$ & 197.00 & Bio & 17 & 39 & 3 & 2 & 39 & 60 & $3.0-3.5$ \\
\hline $782 \mathrm{~B}-37 \mathrm{X}-5,78-80$ & 344.88 & Bio & 27 & 26 & 8 & 4 & 35 & (40) & $(1.5-2.0)$ \\
\hline $731 \mathrm{~A}-40 \mathrm{X}-4,80-82$ & 375.70 & Ter & 18 & 65 & 13 & 4 & 0 & 12 & $<0.5$ \\
\hline 731B-5X-1, 146-148 & 450.36 & Ter & 17 & 61 & 17 & 5 & 0 & 11 & ${ }^{\mathrm{b}} \mathrm{ND}$ \\
\hline $731 C-4 R-1,34-36$ & 560.54 & Ter & 13 & 67 & 18 & 2 & 0 & 11 & ND \\
\hline $731 \mathrm{C}-6 \mathrm{R}-1,97-99$ & 619.07 & Ter & 20 & 64 & 13 & 3 & 0 & 9 & ND \\
\hline $731 \mathrm{C}-8 \mathrm{R}-4,34-36$ & 80.74 & Ter & 30 & 57 & 10 & 3 & 0 & 10 & ND \\
\hline $731 \mathrm{C}-12 \mathrm{R}-3,93-95$ & 795.43 & Ter & 18 & 60 & 21 & 2 & 0 & 14 & ND \\
\hline $731 \mathrm{C}-16 \mathrm{R}-2,1-3$ & 908.81 & Ter & 24 & 57 & 15 & 4 & 0 & 11 & ND \\
\hline $731 \mathrm{C}-21 \mathrm{R}-1,15-17$ & 955.55 & Ter & 23 & 57 & 16 & 4 & 0 & 12 & ND \\
\hline $731 \mathrm{C}-24 \mathrm{R}-1,46-48$ & 984.96 & Ter & 23 & 59 & 15 & 3 & 0 & (12) & ND \\
\hline
\end{tabular}

Abbrevaitions: $\mathrm{Ter}=$ terrigenous sediments, $\mathrm{Bio}=$ biogenic sediments, $\mathrm{Sm}=$ smectite and mixed-layer clays, $\mathrm{Il}=$ illite, $\mathrm{Chl}=$ chlorite, $\mathrm{Kao}=$ kaolinite, $\mathrm{Ply}=$ palygorskite, $\mathrm{ND}=$ no data.

a Calcium carbonate and organic carbon concentrations are from measurements made on board the JOIDES Resolution during Leg 117 (Prell, Niitsuma, et al., 1989). Values are for samples immdiately adjacent to fabric samples, or for Site 723 within $25 \mathrm{~cm}$ of the fabric sample interval. Intervals for which carbon analyses were not performed are represented by values in parenthesis which are from the nearest interval of similar lithology.

b Organic carbon analyses were not performed for samples below $402 \mathrm{mbsf}$ at Site 731 . Analyses performed on similar sediments at Sites 722 and 731 indicate the organic carbon concentration is probably $<0.20 \%$.

of randornly arranged nannofossils embedded in a fine-grained matrix of microcrystalline carbonate (micarb) particles and lesser amounts of clay minerals (Fig. 8A). Porosity of near-surface samples from Oman margin Sites 723 and $728(58 \%$ at both sites) is significantly less than that of the Owen Ridge sediment $(66 \%)$. The marly nannofossil ooze at Site 723 displays large open voids (Fig. 9A), but also a greater abundance of silt-sized particles accounting for its lower porosity. The fine-grained matrix in this sample differs from that of the near-surface sample at Site 722 and primarily consists of clay minerals and, based on the moderately high organic carbon concentration $(2.0 \%-2.5 \%)$, organo-mineral aggregates. At Site 728 the amount of finegrained matrix in the sample from 15 mbsf is less than that in shallow samples from Sites 722 and 723 , and the sediment is largely a cluster of randomly arranged coccoliths (Fig. 10A).

Only minor fabric changes were observed in more deeply buried biogenic sediments from the Owen Ridge and Oman margin. Samples from both areas display little change in particle orientation and only a slight increase in fragmented microfossils. There is little evidence of significant dissolution of microfossils or reprecipitation of calcite over the depth intervals examined at Sites 722, 723, and 728. At Site 722 sediments at 185 mbsf have a porosity of $59 \%$ and show a densely packed matrix of micarb particles and a noticeable reduction in pore size relative to the sample from 2 mbsf (Fig. 8B). The sample from 306 mbsf at Site 722 (Fig. 8C) is from the biogenic-silicarich Unit II and is characterized by an open fabric with large pore spaces and high porosity $(74 \%)$. Samples from $77 \mathrm{mbsf}$ at Site 723 (Fig. 9B) and 81 mbsf at Site 728 (Fig. 10B) contain abundant fine-grained matrix characterized by particles and particle aggregates with thin "feathery" projections. The appearance of these fine-grained particles resembles organo-mineral aggregates in organic-rich sediments from the Peru margin, described by Reimers (1982). The organic content of these sediments is high, $3.8 \%$ for the Site 723 sample and $4.8 \%$ for the Site 728 sample. At both sites porosity of the samples from approximately $80 \mathrm{mbsf}$ is $5 \%$ higher than that of near-surface samples (Table 2), attesting to the higher organic carbon concentration (Table 3 ) and greater abundance of clay-sized particles (Table 2). At Site 723 sediments at 368 mbsf have an organic carbon content comparable to those at $77 \mathrm{mbsf}$; however, the fine-grained particles that comprise the matrix appear more densely packed (Fig. 9C), lacking the feathery or fluffy appearance of aggregates in the sample from 77 mbsf. Porosity of the sample from $368 \mathrm{mbsf}$ is $56 \%$, compared to $63 \%$ for the sample at $77 \mathrm{mbsf}$. At Site 723 the porosity at $368 \mathrm{mbsf}$ is close to that of the near-surface sediments; however, the sediments differ in that the deeper sample is characterized by a finer grain size (Table 2) and smaller pore size. The deepest sample examined at Site 728 (345 mbsf) is from the biogenic-silica-rich Subunit IC. Compared to shallower sediments at this site, the porosity at $345 \mathrm{mbsf}$ is high $(62 \%)$; however, the pore size in this sample is noticeably smaller (Fig. 10C) than that of biogenic-silica-rich sediments examined from Site 722 (Fig. $8 \mathrm{C}$ ), which have a po- 

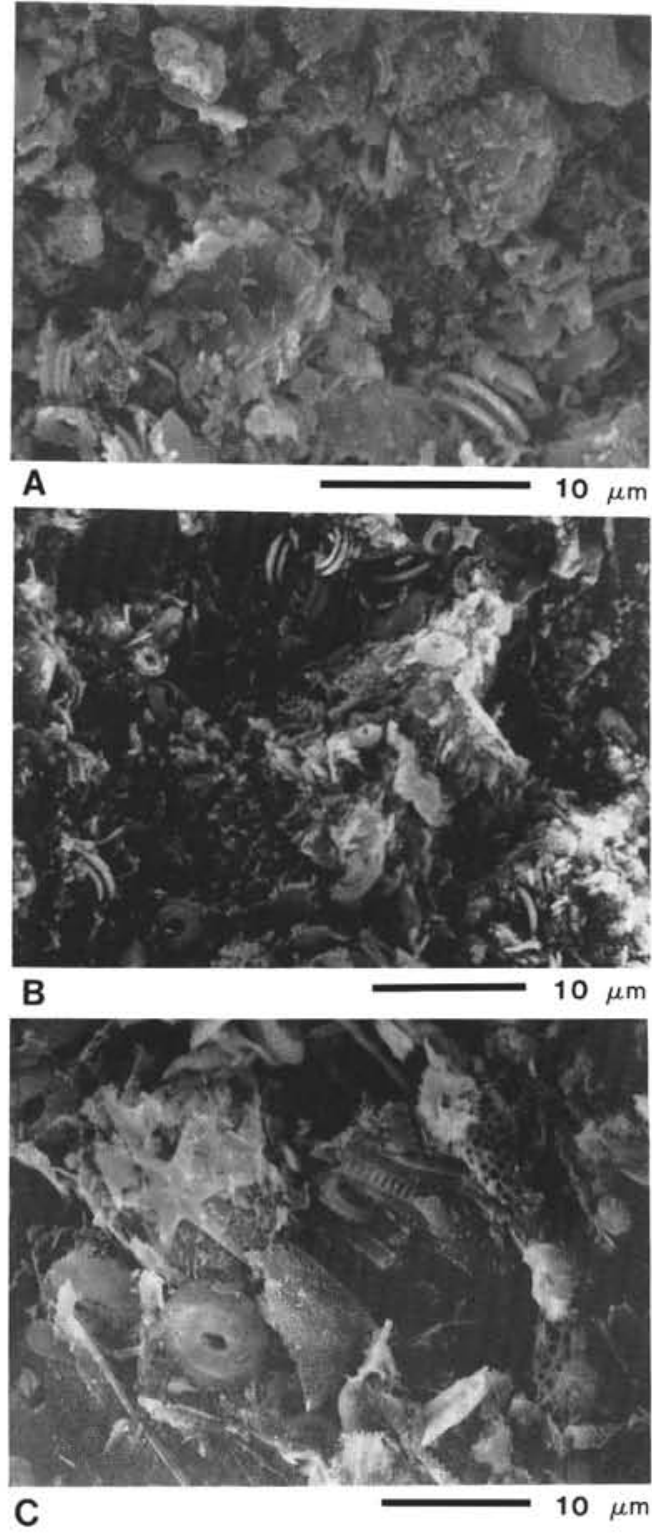

Figure 8. SEM photomicrographs of biogenic sediments from Site 722 (Owen Ridge). A. Sample 117-722A-1H-5, 50-52 cm (2.00 mbsf); nannofossil ooze; porosity $(\phi)=66 \%$. Randomly arranged coccoliths within a fine-grained matrix of predominantly micarb particles. B. Sample $117-722 \mathrm{~A}-20 \mathrm{X}-2,35-37 \mathrm{~cm}$ (185.15 mbsf); nannofossil ooze; $\phi=59 \%$. Randomly arranged nannofossils embedded in a densely packed, finegrained matrix. Note the reduction in pore size relative to $\mathbf{A}$ and a wellpreserved discoaster in the upper right corner. C. Sample 117-722B$33 \mathrm{X}-2,25-27 \mathrm{~cm}$ (306.45 mbsf); diatomaceous marly nannofossil chalk; $\phi=74 \%$. Open fabric formed by a mixture of diatoms, radiolarians, and nannofossils. Inter- and intra-particle porosity is high. A well-preserved discoaster is present in the upper left corner. Coccoliths along the left side display minor etching and calcite overgrowths. Photomicrographs in this figure and subsequent figures are views normal to bedding, with bedding approximately aligned horizontally on the photomicrograph.


Figure 9. SEM photomicrographs of biogenic sediments from Site 723 (Oman margin). A. Sample 117-723A-1H-5, 53-55 cm (6.53 mbsf); marly nannofossil ooze; $\phi=58 \%$. Random fabric with large pores and finegrained matrix containing more clay minerals than that at Site 722 . Note abundant silt grains along the top. B. Sample 117-723A-9H-2, 48-50 cm (77.38 mbsf); marly nannofossil ooze; $\phi=63 \%$. Organic-rich sediment $\left(\mathrm{C}_{\text {org }}=3.9 \%\right)$ with matrix of clay minerals and organo-clay aggregates. C. Sample 117-723B-39X-5, 79-81 cm (368.39 mbsf); marly nannofossil chalk; $\phi=56 \%$. Organic-rich sediments with fine-grain matrix more densely packed than that of $\mathbf{B}$ and a noticeable reduction of pore size. 

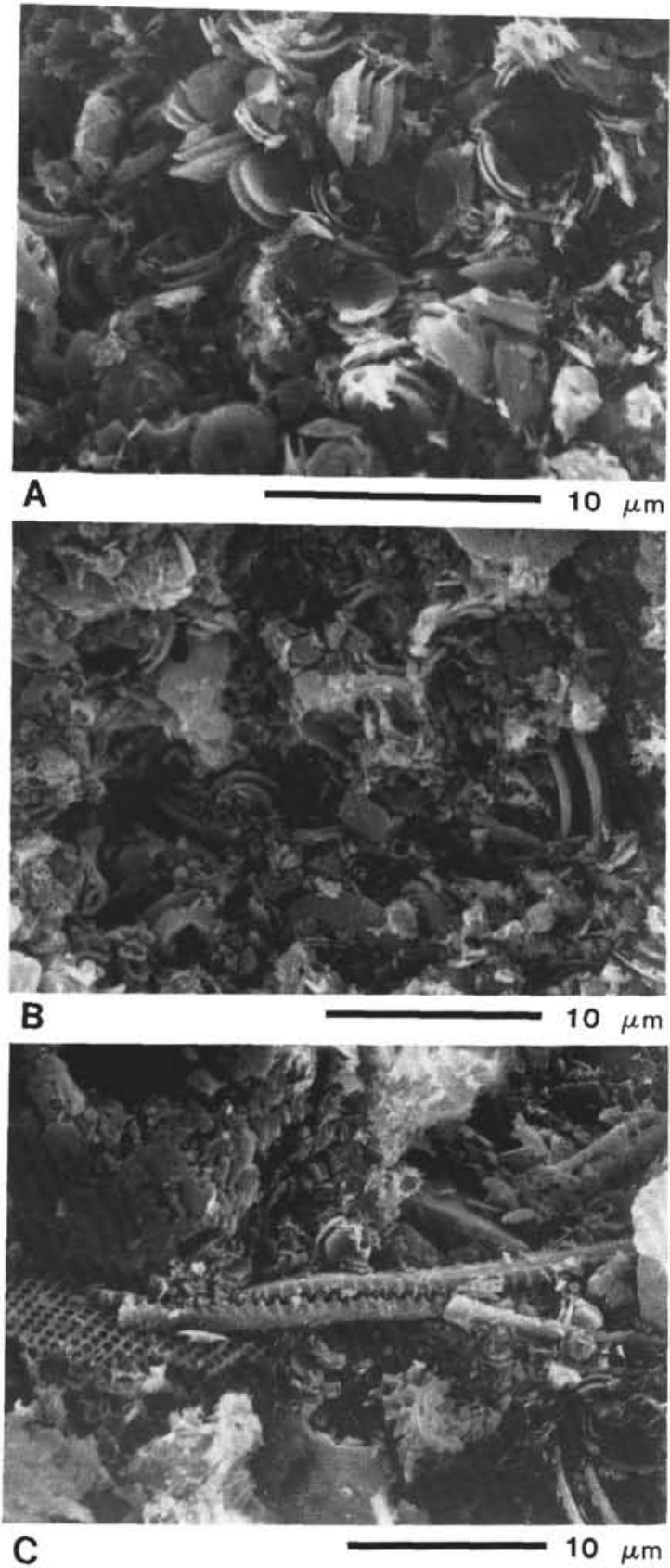

Figure 10. SEM photomicrographs of biogenic sediments from Site 728 (Oman margin). A. Sample 117-728A-2H-4, 82-84 cm (14.92 mbsf); marly nannofossil ooze; $\phi=58 \%$. Random cluster of coccoliths in a clay matrix. B. Sample $117-728 \mathrm{~A}-9 \mathrm{H}-4,78-80 \mathrm{~cm}$ (81.38 mbsf); marly nannofossil ooze; $\phi=63 \%$. Organic-rich sediments $\left(C_{\text {org }}=4.8 \%\right)$ similar to those at 77 mbsf at Site 723 (Fig. 9B). The sediment contains more fine-grained matrix and has a higher porosity than that of $\mathbf{A}$. Note a slight increase in numbers of etched and fragmented coccoliths. C. Sample 117-728B-37X-5, 78-80 cm (344.88 mbsf); marly nannofossil chalk; $\phi=62 \%$. Diatom-rich sediments of Subunit IC. Pore size is smaller than that of siliceous-rich sediments at Site 722 (Fig. 8C). Note the pyrite framboid in the upper left corner. rosity of $74 \%$. Lower porosity of the diatomaceous sediments at Site 728 , compared to similar sediments at Site 722 , is possibly a result of a slightly higher silt content (Table 2). The organic carbon concentration at $345 \mathrm{mbsf}$, approximately $1.5 \%-2.0 \%$, is lower, than that of the sample from $81 \mathrm{mbsf}$ at Site 728, and the fine-grained matrix appears to contain a greater abundance of clay particles.

Downsection changes in particle orientation in biogenic sediments were quantified for samples from Site 722. Quantifying the fabric changes was more difficult for biogenic sediments than for terrigenous sediments because of the lesser abundance of asymmetric or platy particles in the biogenic sediments. Histograms of particle orientation for the Site 722 samples (Fig. 11) show little change in particle alignment downsection. The particle counts are also characterized by high variability between duplicate analyses (Fig. 11). The histograms display little indication of a preferred particle orientation with most of the measured particle angles lying in broad modes between $30^{\circ}$ and $70^{\circ}$ and between $110^{\circ}$ and $150^{\circ}$ relative to bedding.

\section{Terrigenous Sediments}

The terrigenous turbidites sampled at Sites 720,722 , and 731 are very fine-grained with clay percentages ranging from $20 \%$ to $69 \%$ (Table 2). Sand content of the terrigenous samples is negligible, with the exception of one sandy turbidite sample from 909 mbsf at Site 731 which contains $20 \%$ sand (Table 2). Composition of the terrigenous sediment samples is relatively uniform. Illite is the dominant clay mineral in the sediments. Samples from Site 720 display a greater abundance of illite than those from Sites 722 and 731. The range for illite abundance at Site 720 is $69 \%-86 \%$, whereas at Sites 722 and 731 illite abundance ranges from $54 \%$ to $67 \%$ (Table 3 ). Other clay minerals present in the terrigenous sediments include chlorite $(8 \%-30 \%)$, smectite/mixed layer clays $(2 \%-30 \%)$, and kaolinite $(1 \%-5 \%)$. The terrigenous samples are characterized by low calcium carbonate concentration $(9 \%-14 \%)$ and organic carbon concentrations less than $0.5 \%$ (Table 3 ).

The combination of terrigenous sediment samples from the Indus Fan and Owen Ridge provides a record of fabric change from 45 to $985 \mathrm{mbsf}$. Because of the pelagic interval capping the section at Site 720 and poor core recovery immediately below, the sample at 45 mbsf was the shallowest terrigenous sample obtained. The fabric of sediments at $45 \mathrm{mbsf}$ consists of randomly arranged small clay domains (two to three platelets?) and silt particles dispersed in the clay matrix (Fig. 12A). Both edge-toface and face-to-face arrangements of domains are present within this sediment, with edge-to-face configurations predominating. The sediment fabric has an open appearance because of the large pore spaces and small flocculated domains. Smaller pore spaces and slightly larger domains accompany the reduction in porosity from $57 \%$ at $45 \mathrm{mbsf}$ to $53 \%$ at $193 \mathrm{mbsf}$ at Site 720 (Fig. 12B). An increase in face-to-face and stepped face-to-face contacts contributes to the larger domain size at 193 mbsf. Most particles in this sediment are oriented at high angles oblique to bedding, and the fabric retains an open appearance.

Terrigenous sediments from a depth of 376 mbsf were sampled at both Sites 720 and 731 . The two samples have nearly the same porosity, $46 \%$ at Site 720 and $45 \%$ at Site 731 , similar clay mineralogy and carbon composition (Table 3 ), and generally similar fabrics (Figs. 12C and 13A). The sediments differ somewhat texturally with the sample from Site 731 having a finer grain size ( $58 \%$ clay) than the sample from Site 720 ( $41 \%$ clay). The samples differ more significantly in age. At 376 mbsf sediments at Site 720 are Pleistocene in age, whereas those at Site 731 are middle Miocene in age. Both samples from 376 mbsf show significant differences in fabric compared with the terrigenous sediments from shallower depths. The fabric of the deeper sedi- 

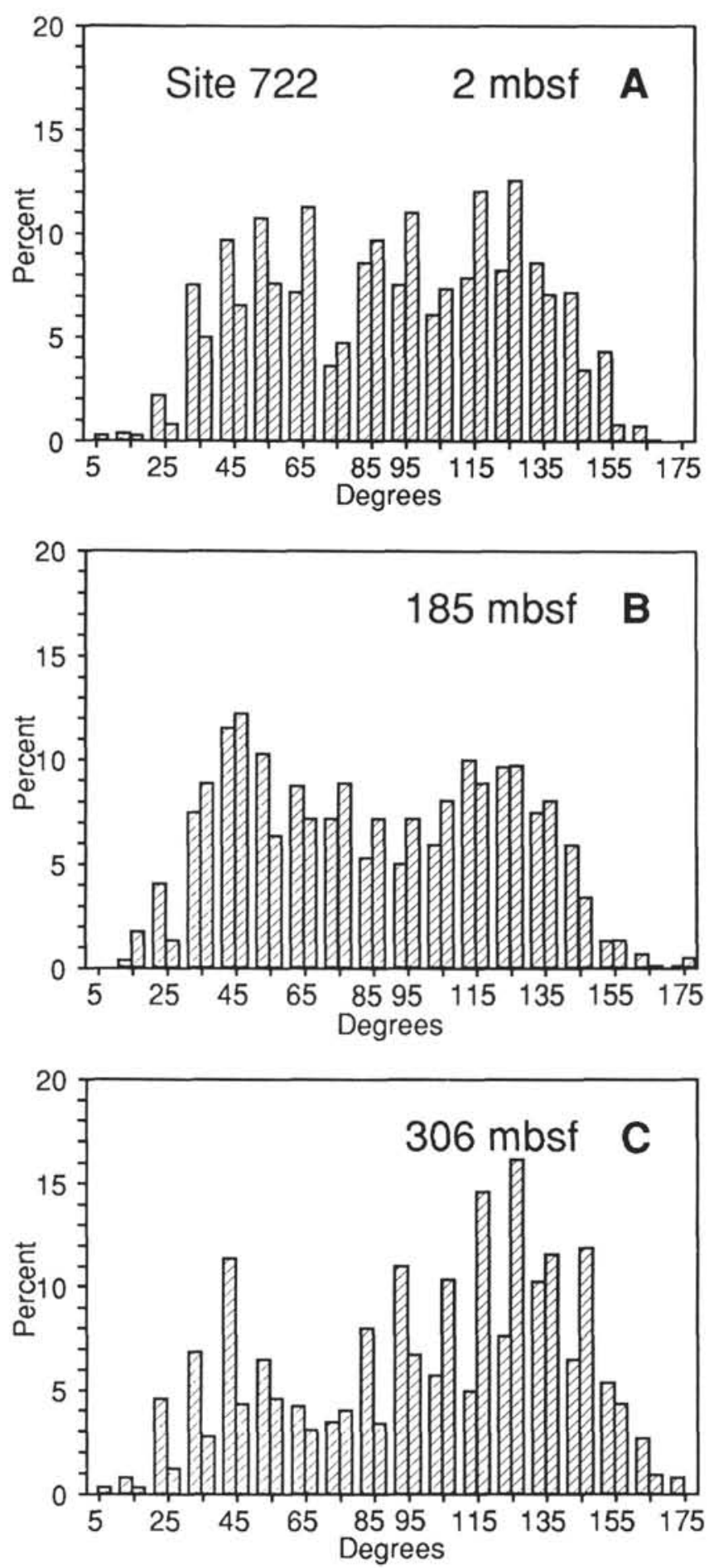

Figure 11. Particle orientation histograms for biogenic sediments from Site 722. Histograms in this figure and Figures 14 and 15 show particle angles ranging from $0^{\circ}$ to $180^{\circ}$ relative to bedding. Class size for the histograms is $10^{\circ}$. Results of duplicate analyses are shown on the histograms as two bars for each class interval. A. Sample 117-722A-1H-5, 50-52 cm. B. Sample 117-722A-20X-2, 35-37 cm. C. Sample 117-722B$33 \mathrm{X}-2,25-27 \mathrm{~cm}$. SEM photomicrographs of these samples are shown in Figure 8 .
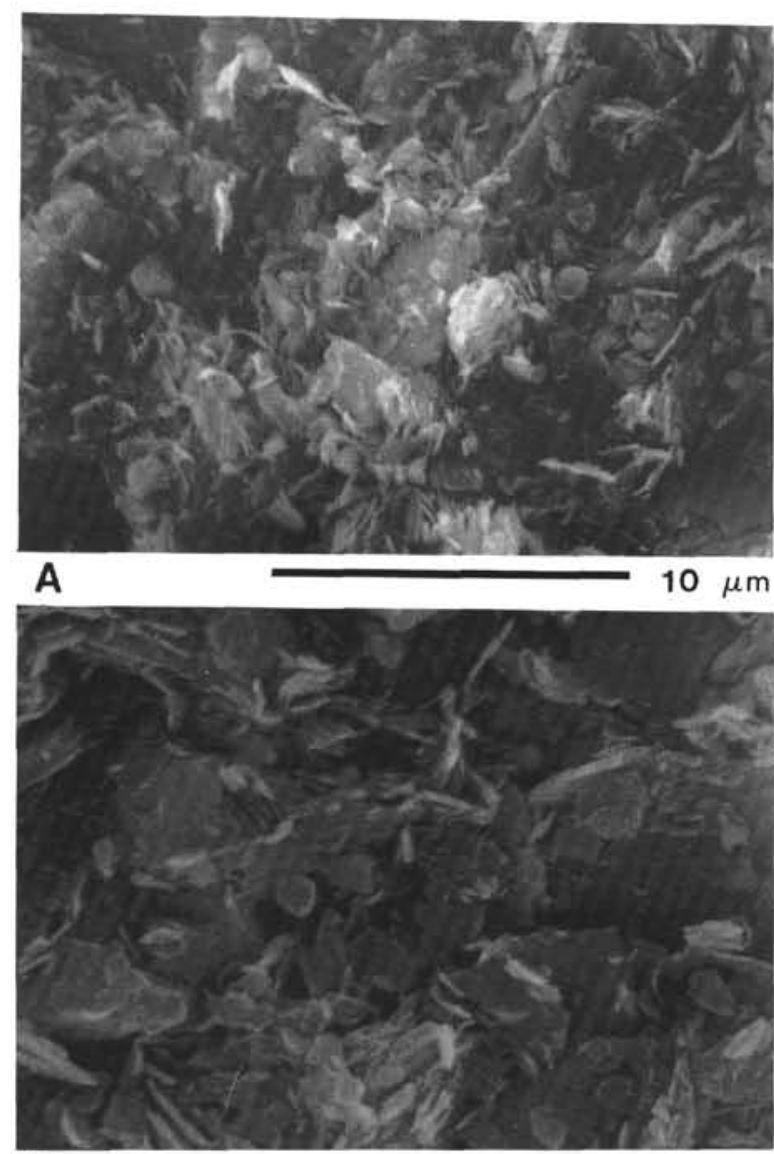

B

$10 \mu \mathrm{m}$

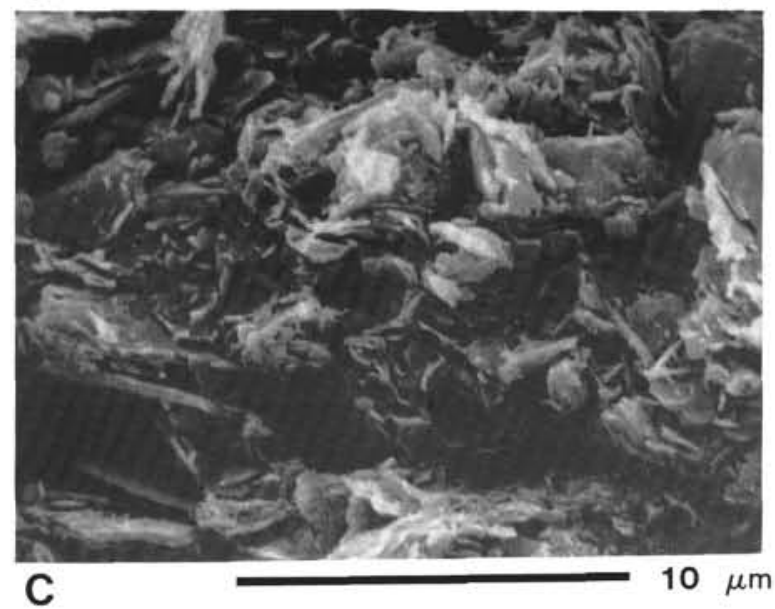

Figure 12. SEM photomicrographs of terrigenous sediments from Site 720 (Indus Fan). All samples are clayey silts. A. Sample 117-720A-5X-5, $87-89 \mathrm{~cm}(45.07 \mathrm{mbsf}) ; \phi=57 \%$. Open fabric of randomly arranged small, flocculated clay domains and silt particles. B. Sample 117-720A$21 \mathrm{X}-1,49-51 \mathrm{~cm}$ (193.49 mbsf); $\phi=53 \%$. Clay domains strongly oblique to bedding. Note the increase in size of domains relative to $\mathbf{A}$. C. Sample 117-720A-40X-1, 26-28 cm (376.16 mbsf); $\phi=46 \%$. Densely packed clay domains and silt grains with particle alignment roughly parallel to bedding. 


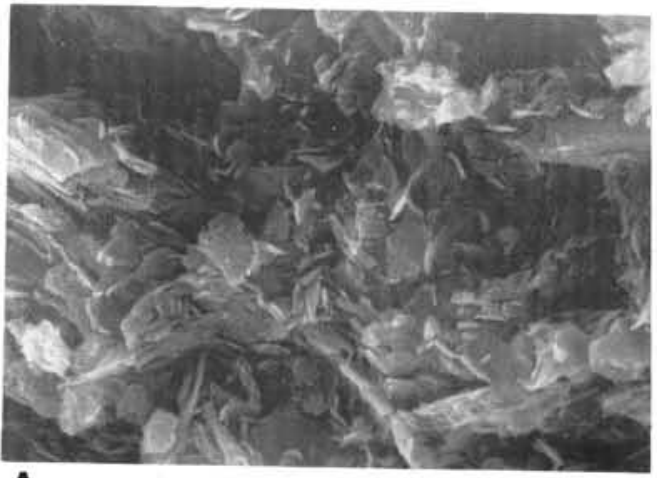

A $10 \mu \mathrm{m}$

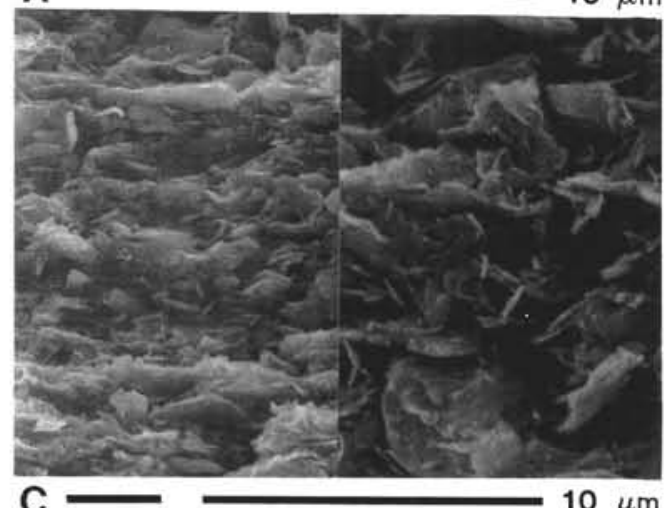

$\mathrm{C}$

$10 \mu \mathrm{m}$

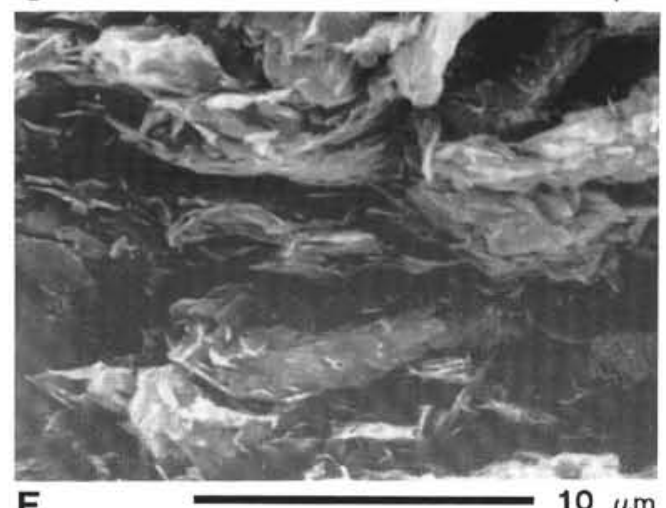

E
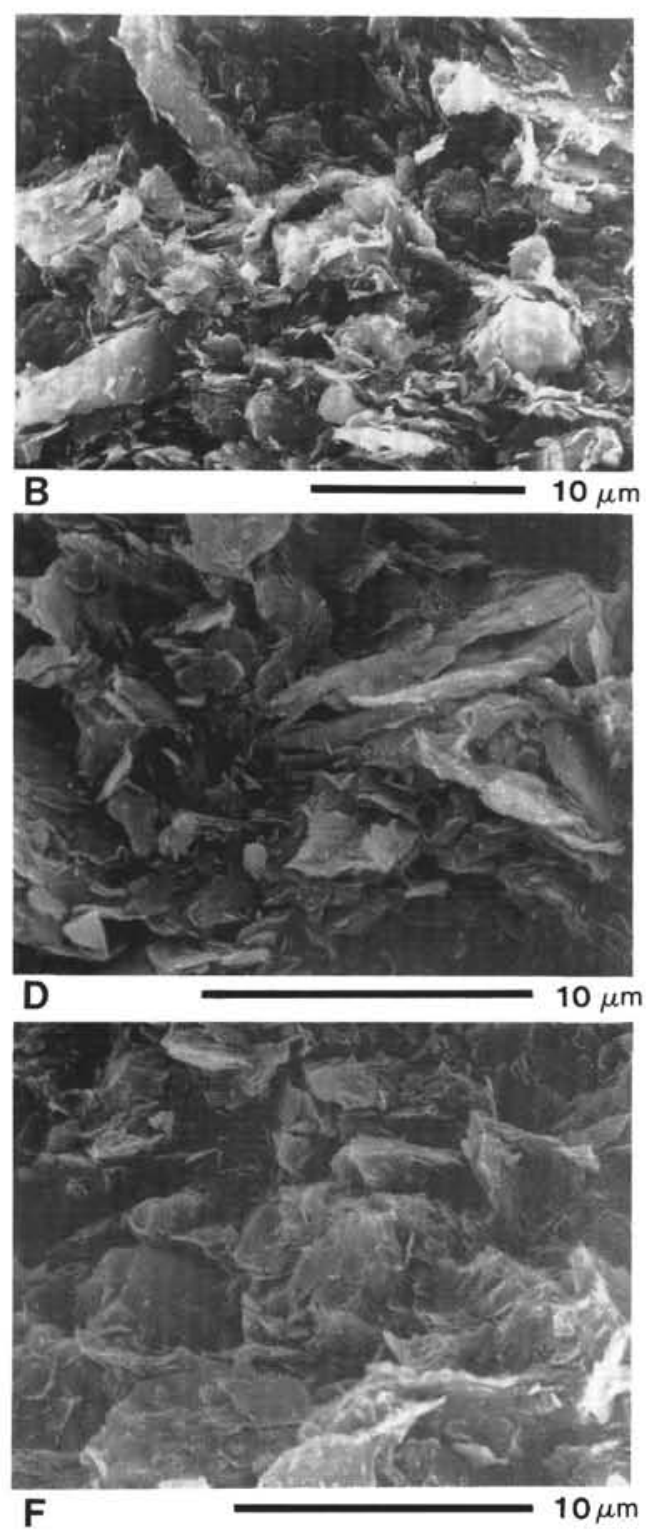

Figure 13. SEM photomicrograph of terrigenous sediments from Site 731 (Owen Ridge). All samples are silty claystones. A. Sample 117$731 \mathrm{~A}-40 \mathrm{X}-4,80-82 \mathrm{~cm}(375.70 \mathrm{mbsf}) ; \phi=45 \%$. Fabric consisting of a variety of domain habits: large domain books (face-to-face contacts), flocculated domains (edge-to-face contacts), and linking domains (edge-to-edge contacts). Fabric shows initial stage of deformation of domains surrounding silt grains. B. Sample 117-731C-6R-1, 97-99 cm $(619.07 \mathrm{mbsf}) ; \phi=40 \%$. Silt grains dispersed in clays with weak orientation of domains parallel to bedding. Clay particles bonded obliquely to silt grains. C. Sample $117-731 \mathrm{C}-8 \mathrm{R}-4,34-36 \mathrm{~cm}(680.74$ mbsf); $\phi=39 \%$. Low magnification shows strong preferred particle orientation parallel to bedding. High magnification shows retention of flocculated fabric, especially adjacent to silt grains. D. Sample 117-731C-12R-3, 93-95 cm (795.43 mbsf); $\phi=33 \%$. Densely packed fabric consisting of interlocking particles. Size of clay domains has increased to the extent to that they are difficult to distinguish from silt particles. E. Sample 117-731C-21R-1, 15-17 cm ( $955.55 \mathrm{mbsf}) ; \phi=34 \%$. Well-developed preferred orientation parallel to bedding. Note long, narrow edge-to-edge chains of clay domains and narrow channel-like pores parallel to domains. F. Sample $117-731 \mathrm{C}-24 \mathrm{R}-1,46-48 \mathrm{~cm}$ ( $984.96 \mathrm{mbsf}) ; \phi=30 \%$. Silt grains dispersed in a densely packed clay matrix. Particle alignment is less than that of $\mathbf{E}$ and areas of flocculated domains are present. 
ments is characterized by more densely packed clay domains, smaller pore spaces, and a more massive appearing fabric. Domains appear in edge-to-face, face-to-face, and edge-to-edge habits (Fig. 13A); however, there is a noticeable greater alignment of particles roughly parallel to bedding. Silt particles remain dispersed in the clay matrix at 376 mbsf; although, compaction-induced curvature of clay domains around silt particle is discernible (Figs. 12C and 13A).

Trends in fabric transformation (reduction in pore size, increase in domain size, and increased alignment parallel to bedding) that characterize changes between 193 and 376 mbsf continue with increased burial depth but at a slower rate. At 619 mbsf particles are more densely packed; however, the flocculated clay fabric typified by edge-to-face contacts is preserved. This arrangement is particularly evident in domains located in close proximity to silt grains (Fig. 13B). Recognition of the flocculated clay fabric in part is dependent on the scale at which the sediment fabric is viewed. Sediments from 681 mbsf viewed under relatively low magnification show a strong alignment of particles parallel to bedding (Fig. 13C). At higher magnification the retention of the flocculated fabric is clearly visible. Continued increase in domain size with increasing burial depth is evident in the sample from 795 mbsf (Fig. 13D). The porosity of this sample is $33 \%$, and the fabric has a dense, massive appearance. Clay domains in this sediment are approaching silt size, and distinction of silt grains and large domains is difficult. The fabric of sediments sampled at 956 mbsf has a distinct lineated appearance as a result of long, thin domains linked edge-to-edge and oriented parallel to bedding (Fig. 13E). Pore spaces in this sediment are long, narrow, and parallel to domains. It is notable that the sample from $956 \mathrm{mbsf}$ has the highest clay content $(69 \%)$ of the terrigenous sediments examined (Table 2). The deepest sample examined is from $985 \mathrm{mbsf}$ at Site 731. A greater abundance of silt in this sample (the clay content is $51 \%$ ) gives the fabric a more weakly oriented appearance (Fig. 13F) than that at 956 mbsf. Domains are large in this sediment, and contacts between silt and clay particles are not easily distinguished. Areas of flocculated clay fabric, however, still occur adjacent to silt grains.

Measurement of particle orientation for terrigenous sediments from Sites 720 and 731 reveals consistent downsection trends in changing particle alignment. Compared with measurements of particle orientation of biogenic sediments at Site 722 , there is also a greater uniformity of the duplicate analyses performed for each sample. The particle orientation histogram for the sample from 45 mbsf at Site 720 is weakly bimodal with most of the particles oriented at high angles to bedding (Fig. 14A). The fabric orientation of this sample is comparable with that documented for pelagic clays at shallow burial depths (Burkett et al., 1987). The histogram for the sample from 193 mbsf shows a greater separation of the modes; however, particles remain strongly oblique to bedding (Fig. 14B). Measurements of particle orientation for samples from 376 mbsf at Sites 720 and 731 show that a distinct change in fabric occurs between this depth and 193 mbsf. Histograms for the samples from 376 mbsf show a clear shift of the modes to angles more nearly parallel to bedding and a sharp reduction of particle angles ranging from $70^{\circ}$ to $110^{\circ}$ relative to bedding (Figs. $14 \mathrm{C}$ and $15 \mathrm{~A}$ ). Downsection at Site 731 the trend toward greater alignment of particles with bedding continues gradually, with a slight reversal of the trend between 956 and 985 mbsf (Fig. 15). Results of the particle orientation measurements for terrigenous sediments are summarized in Figure 16 in which the percentages of particles oriented at angles of $0^{\circ}-30^{\circ}$ and $150^{\circ}-180^{\circ}$ (\% subparallel) are plotted against depth. Figure 16 shows the distinct change in orientation between 193 and 376 mbsf, a gradual increase in alignment between 376 and $681 \mathrm{mbsf}$, and relatively little change below 681 mbsf.
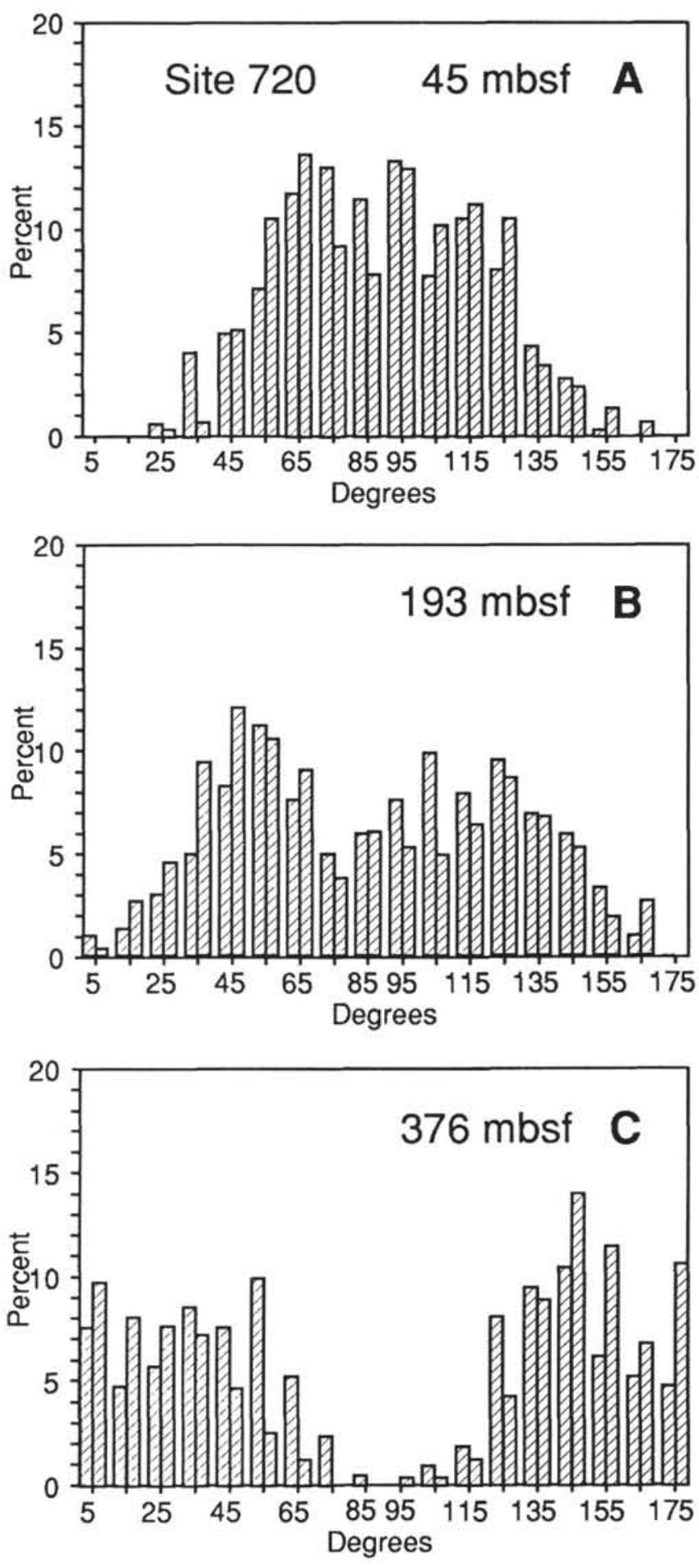

Figure 14. Particle orientation histograms for terrigenous sediments from Site 720. A. Sample 117-720A-5X-5, 87-89 cm. B. Sample 117-720A$21 \mathrm{X}-1,49-51 \mathrm{~cm}$. C. Sample 117-720A-40X-1, 26-28 cm. SEM photomicrographs of these samples are shown in Figure 12.

\section{DISCUSSION}

\section{Fabric Transformations in Biogenic Sediments}

The fabric of nannofossil and marly nannofossil oozes and chalks from the Owen Ridge (Site 722) and Oman margin (Sites 723 and 728) is characterized by randomly oriented microfossils in a fine-grained matrix. The random particle arrangement per- 

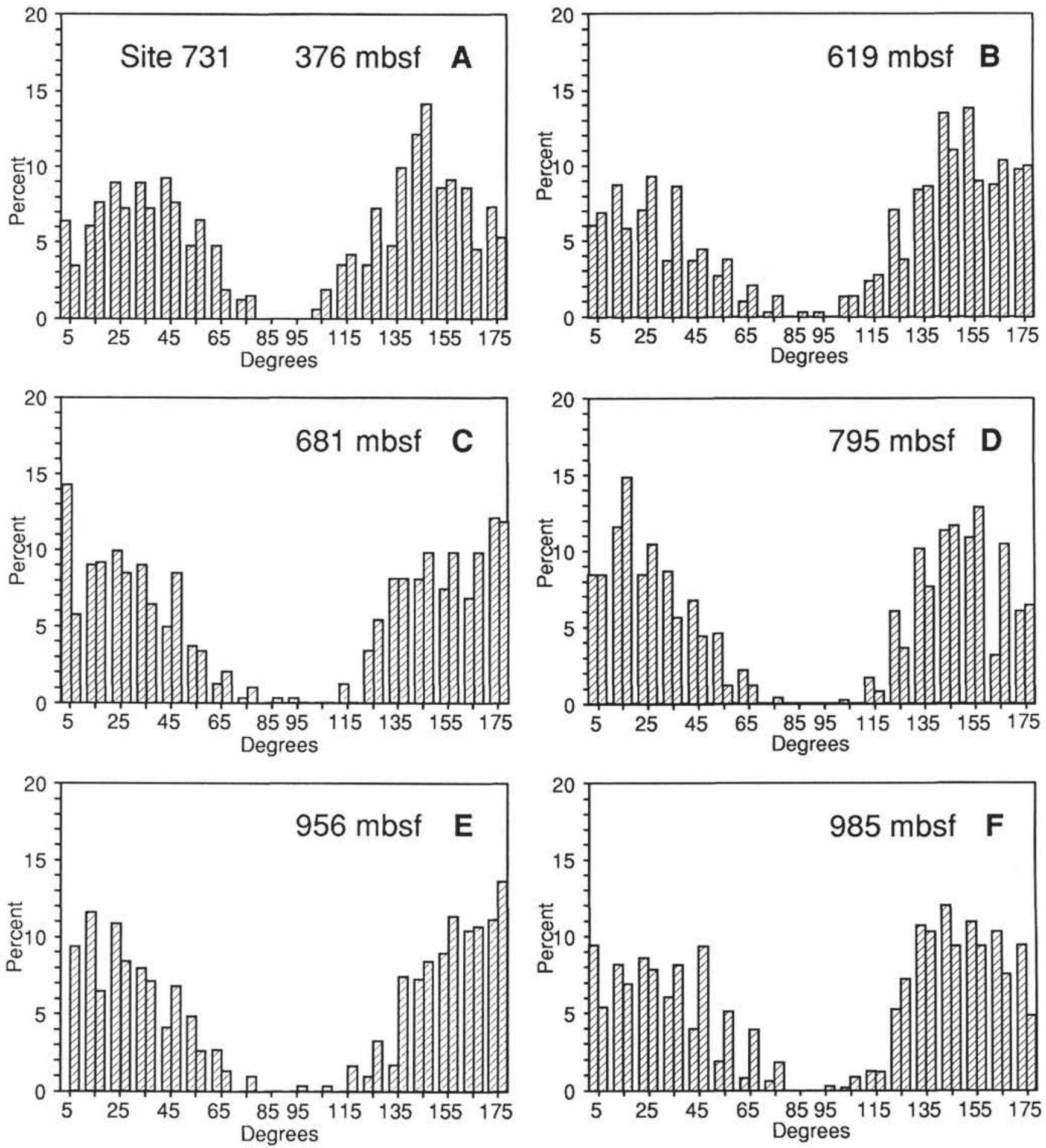

Figure 15. Particle orientation histograms for terrigenous sediments from Site 731. A. Sample 117-731A-40X-4, 80-82 cm. B. Sample 117-731C6R-1, 97-99 cm. C. Sample 117-731C-8R-4, 34-36 cm. D. Sample 117-731C-12R-3, 93-95 cm. E. Sample 117-731C-21R-1, 15-17 cm. F. Sample $117-731 \mathrm{C}-24 \mathrm{R}-1,46-48 \mathrm{~cm}$. SEM photomicrographs of these samples are shown in Figure 13.

sists with burial, over the depth intervals examined at Sites 722 , 723 , and 728 . It is not possible to determine to what extent the particle arrangement represents the original depositional fabric. At all three sites bioturbation is minor to moderate in the sample intervals (Prell, Niitsuma, et al., 1989). Studies of shale fabric have shown that random particle arrangements are a consequence of bioturbation (O'Brien, 1987). Attempts to quantify particle orientation at Site $\mathbf{7 2 2}$ suggest that there is little reorientation of particles with increasing compaction (Fig. 11).

Differences in sediment fabric among Sites 722,723 , and 728 largely reflect differences in composition of the fine-grained matrix and the assemblage of microfossils. Composition of the sediment matrix differs between the Owen Ridge and Oman margin. On the Owen Ridge the matrix is dominated by micro- 


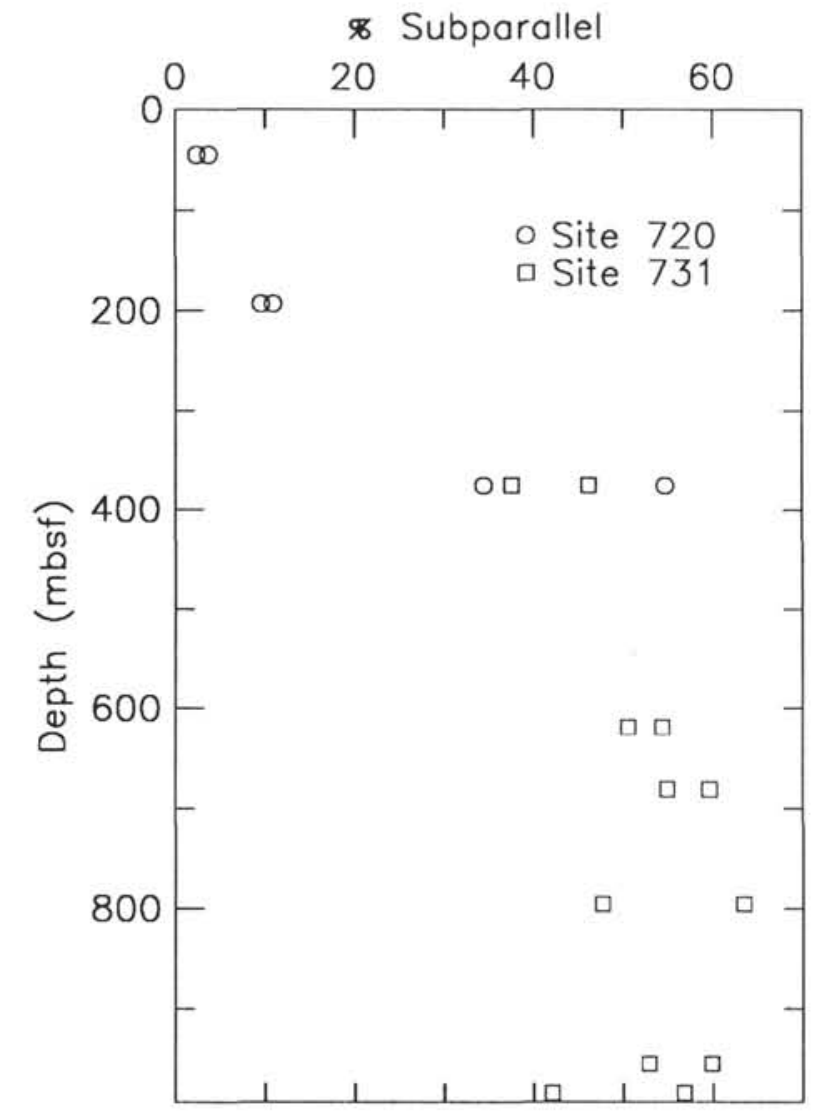

Figure 16. Particle orientation (\% subparallel) vs. depth for terrigenous sediments from Site 720 (circles) and Site 731 (squares). The abscissa (\% subparallel) represents the percentage of particles within the angle ranges of $0^{\circ}-30^{\circ}$ and $150^{\circ}-180^{\circ}$, relative to bedding. The two values plotted at each depth are results of duplicate analyses.

crystalline calcite grains, whereas on the Oman margin there is a greater abundance of clay minerals and organo-mineral aggregates. In both areas the mineralogy of the clay fraction is relatively uniform (Table 3), and clay mineralogical variation does not appear to be a factor affecting fabric change. Samples over the interval 2-185 mbsf at Site 722 (Owen Ridge) indicate that porosity reduction is primarily a consequence of mechanical compaction, producing a more densely packed fine-grained matrix at greater depths. At Sites 723 and 728 this trend is not present between near-surface samples and samples from approximately $80 \mathrm{mbsf}$ because of the greater abundance of organic matter in the deeper sediments. The effect of organic matter on sediment fabric has been shown to be an increase in porosity, as a consequence of formation of porous aggregates of organic matter and clay minerals and adsorption of water on the surface of organic substances (Pusch, 1973). At both Sites 723 and 728 porosity is greater at 80 mbsf than it is in the samples from near the seafloor as a result of higher organic carbon concentration in the deeper sediments. With burial, as evidenced by samples from Site 723, the organic-rich matrix is compacted and porosity is reduced. The most significant fabric difference related to the composition of the microfossil assemblage is associated with the relative abundance of calcareous and siliceous microfossils. Sediments with abundant diatoms and radiolarians are characterized by large voids between particles and extensive intra-particle porosity, as shown by sediments from 306 mbsf at Site 722 (Fig. 8C) and to a lesser extent sediments from 345 mbsf at Site 728 (Fig. 10C).
Garrison (1981) concluded that during diagenesis of deepsea carbonate sediments, gravitational compaction is significant only in the first $50-200 \mathrm{~m}$ of burial and that below these depths, pressure solution and reprecipitation of calcite are the dominant processes. Garrison proposed that chemical diagenetic changes in carbonate sediments follow a progressive sequence which includes: (1) accretionary overgrowth of calcite on discoasters; (2) calcite precipitation on other fossils after compaction has created a grain-supported framework; and (3) connection of the gap between proximal and distal shields of placoliths by secondary calcite and growth of void-filling euhedral calcite crystals within foraminifer chambers. Kim et al. (1985) also identified approximately $200 \mathrm{mbsf}$ as the lower limit for transformations dominated by compaction. A porosity of $50 \%$ characterized this burial depth in the equatorial Pacific sediments studied by Kim et al. (1985).

Changes in the fabric of biogenic sediments at Sites 722 , 723 , and 728 appear to be dominated by mechanical compaction. At all three sites there are only minor indications of increased calcite dissolution and reprecipitation with depth. At Site 722 well-preserved discoasters are present in sediments at 185 and 306 mbsf (Fig. 8), suggesting that chemical diagenesis has not advanced beyond its earliest stage. Planktonic foraminifers, which have been characterized as especially susceptible to dissolution (Schlanger and Douglas, 1974), are moderately well preserved through Unit II (343 mbsf) at Site 722 and for the entire section at Site 723 (Prell, Niitsuma, et al., 1989). At Site 728 planktonic foraminifers are well preserved down to $57 \mathrm{mbsf}$ and poorly preserved below this depth. The abundance of noncalcareous constituents in the Oman margin and to a lesser extent Owen Ridge sediments may account for the lack of chemical diagenetic alteration of the calcareous constituents. Fabrics of the biogenic sediments are largely characterized by microfossils dispersed in fine-grained matrix and are not dominated by grainto-grain contacts. The porosity of all of the biogenic sediment samples examined is above the boundary of $50 \%$ identified by Kim et al. as the point where diagenetic processes changes from domination by compaction to predominantly pressure solution at grain contacts and reprecipitation of calcite. Matter (1974) identified a sharp increase in lithification of calcareous sediments by cementation at a burial depth of 425 mbsf at DSDP Site 223, located on the western edge of the Owen Ridge. On the crest of the Owen Ridge, Unit III (343.4-411.1 mbsf at Site 722 and 240.9-320.1 mbsf at Site 731) displays a rapid decrease in porosity (Figs. 3 and 4) and increase in velocity (Fig. 5A) indicating that such a jump may occur within this unit. The poor preservation state of calcareous microfossils in Unit III (Prell, Niitsuma, et al., 1989) supports this inference.

\section{Fabric Transformations in Terrigenous Sediments}

Over the depth interval 45-985 mbsf on the Indus Fan and Owen Ridge, the fabric of fine-grained terrigenous sediments changes from a flocculated clay fabric with most particles oriented at high angles to bedding to a fabric in which most particles have reoriented to be roughly parallel to bedding. These changes coincide with a progressive decrease in porosity from $57 \%$ to $30 \%$. Reorientation of particles with burial is accompanied by an increase in the size of clay domains primarily through an increase in particles aggregated in a face-to-face configuration. As these transformations occur the appearance of the sediment changes from an open structural arrangement of particles with relatively large voids to a densely packed sediment in which it is often difficult to distinguish clay aggregates from silt grains. Despite the overall particle reorientation and porosity reduction with burial, flocculated clay fabric characterized by edge-to-face domain arrangements are present in the deepest samples, particularly adjacent to silt grains. 
Point counts of particle orientation indicate that reorientation of particles as a consequence of compaction is not a continuous change, but instead is marked by a significant increase in particles oriented at low angles to bedding between the depths of 193 and 376 mbsf (Fig. 16). Below 376 mbsf the rate of change of particle orientation is more gradual. Previous clay fabric studies have shown that flocculated clay aggregates are initially separated by thin chains of clays which break down and allow clays from the broken chains to aggregate into larger domains as compaction proceeds (Pusch, 1973; Bennett et al., 1977, 1981). The change in particle orientation indicated by samples from 193 and 376 mbsf suggests that in the interval between these depths the overburden stress exceeds the strength of the linking chains or many of the edge-to-face configurations and a fabric more aligned with bedding results. The increase in velocity anisotropy with depth in Unit IV at Site 731 also reflects the progressive alignment of particles with bedding (Fig. 5). Increasing velocity anisotropy in terrigenous sediments is generally assumed to represent increasing parallel alignment of tabular sediment particles (Boyce, 1980). There is not a direct correspondence between change in velocity anisotropy and results of point counts of particle orientation (Fig. 16). The velocity anisotropy of the sample from $376 \mathrm{mbsf}$ is low $(0.3 \%)$; however, the increase in anisotropy between 376 and 681 mbsf (Fig. 5) agrees with the increase in percentage of subparallel particles (Fig. 16). Below 900 mbsf velocity anisotropy increases noticeably; although, the percentage of subparallel particles shows little change. It is possible that this lack of correspondence between velocity measurements and SEM observations is the result of velocity anisotropy reflecting larger scale fabric changes than what is viewed by the SEM (R. H. Bennett, pers. comm., 1989). However, velocity anisotropy at 985 mbsf is lower than that at 956 mbsf which is consistent with the difference in percentage of subparallel particles between these two sample depths.

Fabric differences related to variation in clay mineralogy are difficult to determine for the fine-grained turbidites because of their relatively uniform clay-mineral assemblage. Illite is the dominant clay mineral in the terrigenous sediments at Sites 720 , 722 , and 731 , with primarily chlorite and smectite constituting the rest of the clay fraction (Table 3 ). The fabric of these sediments is consistent with that of illite-rich sediments which has been characterized as haphazardly arranged plate-shaped particles of varying size (Pusch, 1973). The morphology of chlorite in sediments is generally similar to that of illite (Mitchell, 1976), whereas smectite-rich sediments are characterized by thin parallel sheets in continuously interwoven networks (Pusch, 1973). The most significant difference in clay mineralogy among the terrigenous sediments examined is the higher illite concentration of samples from 45 and $193 \mathrm{mbsf}$ at Site 720 (Table 3). The greater abundance of illite in these samples may contribute in part to the much lower degree of particle alignment observed in these sediments (Figs. 14 and 16).

Fabric differences associated with differences in grain size are minor in the terrigenous sediments. Sediments containing large amounts of silt retain areas of flocculated clay fabric adjacent to the silt particles when compacted. With increasing depth clay domains are also deformed to bend around the silt particles. The sample from 955 mbsf at Site 731 contains the highest percentage of clay $(69 \%)$ determined for the fabric samples and is characterized by well-developed preferred orientation of domains and domains linked parallel to bedding. The extent to which variations in the relative abundance of silt- and clay-sized particles affects the reorientation of particles with depth is unclear. Samples from 376 mbsf at Sites 720 and 731 are characterized by a $17 \%$ difference in clay percentage (Table 2); however, the orientation of particles in these two samples is similar (Figs. $14 \mathrm{C}, 15 \mathrm{~A}$, and 16).
The effects of time on compaction of the terrigenous sediments can only be evaluated at the $376 \mathrm{~m}$ depth at which there are samples from both Sites 720 and 731 . The age difference between the two samples is significant, Pleistocene at Site 720 and middle Miocene at Site 731; however, the general appearance of the fabric of the two samples is similar, indicating that mechanical compaction is the primary process affecting these sediments. There is little indication of chemical diagenetic alteration of deeper samples at Site 731, suggesting that gravitational compaction has been the principal process responsible for porosity reduction in the composite 985 -m-thick terrigenous section examined.

Development of fissility has been a topic of many studies of deeply buried fine-grained terrigenous sediments, which have been reviewed by Moon and Hurst (1984). The deeply buried silty claystones at Site 731 lack fissility, as defined by splitting of thin laminae along bedding planes, despite the downsection trend for alignment of particles parallel to bedding. Odom (1967) concluded that development of fissility requires high organic content $(6 \%-30 \%)$, which causes clays to be initially oriented in a dispersed fabric of particles aligned with bedding. The low organic carbon concentration of terrigenous sediments of the Indus Fan (Table 3) most likely precluded the initial development of such a dispersed fabric. Bioturbation has been recognized as a process that inhibits development of fissility (Byers, 1974), and minor bioturbation of the upper $1-5 \mathrm{~cm}$ of fine-grained turbidite sequences characterizes sediments at Site 731 (Prell, Niitsuma, et al., 1989). The fabric of terrigenous sediments at Sites 720,722 , and 731 , however, does not have the appearance of individual random clay particles described by O'Brien (1987) as being typical of highly bioturbated sediment. Terrigenous sediments of the Owen Ridge and Indus Fan are probably best characterized as having been originally deposited with a flocculated clay fabric, and although particles in deeply buried sediments have reoriented to the point where most are roughly aligned with bedding, they are not aligned to the extent which characterizes fissility.

Bennett et al. $(1977,1981)$ proposed a model for fabric transformation of fine-grained terrigenous sediments of the Mississippi Delta, extending from the seafloor to $150 \mathrm{mbsf}$. In the model, clay-rich sediments initially display a flocculated fabric and possess high porosity because of many small domains that bond together at their edges, or stepped face-to-face, forming chains that encircle large voids. With compaction, domain size and the number of edge-to-face contacts increases. As porosity continues to decrease, domains become larger by adding particles face-to-face, and the angle between the edge-to-face contacts increases. Lowest porosity is achieved at $150 \mathrm{mbsf}$ in the Mississippi Delta sediments when large linking domains parallel bedding and are separated by narrow elongate voids. Fabric change in terrigenous sediments of the Indus Fan and Owen Ridge roughly follows the model of Bennett et al. (1977, 1981), with the exception that preferred orientation and porosity reduction occur at greater depths in the Arabian Sea sediments. Mississippi Delta sediments differ from terrigenous sediments at Sites 720, 722, and 731 in that the former are smectite-rich and generally contain $80 \%$ clay-sized particles. Higher clay abundance and smectite concentration in the Mississippi Delta sediments may facilitate development of edge-to-edge domains and elongate pores at shallower burial depths than observed on the Indus Fan and Owen Ridge.

\section{SUMMARY}

The fabric of biogenic sediments on the Owen Ridge and Oman margin is characterized by a random arrangement of microfossils in a fine-grained matrix. With burial, up to $306 \mathrm{~m}$ on the Owen ridge and $368 \mathrm{~m}$ on the Oman margin, the random 
particle arrangement persists and chemical diagenetic alteration of sediments is minimal. Differences in the fabric of the biogenic sediments are primarily associated with the composition of the fine-grained matrix and microfossil assemblage. The matrix is predominantly microcrystalline carbonate particles on the Owen Ridge and a mixture of clay minerals and organic matter on the Oman margin. Burial-related fabric changes over the depth intervals examined on the Owen Ridge and Oman margin are primarily a response to gravitational compaction.

Fabric changes in terrigenous sediments from the Indus Fan and Owen Ridge, over the depth interval of 45-985 mbsf, are also dominated by the process of mechanical compaction. The fabric of the fine-grained turbidites at the shallowest depth examined is characterized by randomly oriented grains, small domains oriented in edge-to-face configuration, and large open pore spaces. With burial, porosity is reduced as domain size increases, primarily through an increase in face-to-face configurations, and particles are reoriented to be more nearly parallel to bedding. Maximum preferred orientation was observed at 956 mbsf where sediments contain large domains linked edge-toedge and separated by long narrow pores parallel to bedding. Particle reorientation is not a continuous change but is marked by a significant increase in particle alignment between 193 and 376 mbsf. Although most particles are nearly parallel to bedding at 985 mbsf, particle alignment is not sufficient for development of fissility. Silt abundance influences the fabric of the fine-grained turbidites as a consequence of retention of areas of flocculated clay domains adjacent to silt grains and compaction-induced deformation clays around silt grains. Fabric changes in the fine-grained turbidites of the Indus Fan and Owen Ridge generally conform to the model of fabric transformation proposed for clay-rich sediments of the Mississippi Delta, except that porosity reduction and development of preferred particle orientation occur at greater depths in the turbidites as a consequence of their coarser grain size and greater abundance of illite and chlorite in the clay fraction.

\section{ACKNOWLEDGMENTS}

The authors thank Cindy Bray and Roman Bilak for helping collect the physical properties data and fabric samples. We appreciate the advice on operation of the SEM and other aspects of the research, provided by Ralph Kugler throughout all stages of the study. We also thank Richard Bennett for advice on sample preparation and interpretation of sediment fabrics. The SEM used in this study was purchased with funds provided by the National Science Foundation Grant EAR-86-13639. This research was completed with funds provided by the U.S. Science Program associated with the Ocean Drilling Program, sponsored by the National Science Foundation and the Joint Oceanographic Institutions, Inc. Conclusions expressed in this publication are those of the authors and do not necessarily reflect the view of the National Science Foundation, the Joint Oceanographic Institutions, Inc., or Texas A\&M University.

\section{REFERENCES}

Bennett, R. H., Bryant, W. R., and Keller, G. H., 1977. Clay fabric and geotechnical properties of selected submarine sediment cores from the Mississippi Delta. NOAA Prof. Pap., 9.

1981. Clay fabric of selected submarine sediments: fundamental properties and models. J. Sediment. Petrol., 51:217-232.

Bennett, R. H., Hulbert, M. H., and Bryant, W. R., 1988. The microstructure of fine-grained terrigenous marine sediments-from muds to shale. Proc. Clay Microstruct. Workshop Conf.

Biscaye, P. E., 1965. Mineralogy and sedimentation of recent deep-sea clays in the Atlantic Ocean and adjacent seas and oceans. Geol. Soc. Am. Bull., 76:803-832.
Bowles, F. A., Bryant, W. R., and Wallin, C., 1969. Microstructure of unconsolidated and consolidated marine sediments. J. Sediment. Petrol., 39:1546-1551.

Boyce, R. E., 1980. Determination of the relationships of electrical resistivity, sound velocity, and density/porosity of sediment and rock by laboratory techniques and well logs from deep sea drilling project sites 415 and 416 off the coast of Morocco. In Lancelot, Y., Winterer, E. L., et al., Init. Repts. DSDP, 50: Washington (U.S. Govt. Printing Office), 305-318.

Bryant, W. R., Bennett, R., and Katherman, C., 1981. Shear strength, consolidation, porosity, and permeability of marine sediments. In Emiliani, C. (Ed.), The Sea (Vol. 7): New York (Wiley), 1555-1616.

Burkett, P. J., Bennett, R. H., Li, H., Nastav, F. L., Bryant, W. R., Shepard, L. E., and Chiou, W.-A., 1987. Microstructure of red clay from the central Pacific deep-sea basin: significance to subseabed nuclear waste disposal. Sandia Nat. Lab. [Tech. Rep.J SAND, 862492.

Byers, C. W., 1974. Shale fissility: relation to bioturbation. Sedimentology, 21:479-484.

Carlson, R. L., and Christensen, N. L., 1979. Velocity anisotropy in semi-indurated calcareous deep-sea sediments. J. Geophys. Res., 84: 205-211.

Garrison, R. E., 1981. Diagenesis of oceanic carbonate sediments: a review of the DSDP perspective. Soc. Econ. Paleontol. Mineral., Spec. Publ., 32:181-207.

Heling, D., 1970. Micro-fabrics of shales and their rearrangement by compaction. Sedimentology, 15:247-260.

Hulbert, M. H., and Bennett, R. H., 1975. Electrostatic cleaning technique for fabric SEM samples. Clays Clay Miner., 23:331.

Kim, D.-C., Manghnani, M. H., and Schlanger, S. O., 1985. The role of diagenesis in the development of physical properties of deep-sea carbonate sediments. Mar. Geol., 69:69-91.

Kolla, V., Be, A., and Biscaye, P. E., 1976. Calcium carbonate distribution in the surface sediments of the Indian Ocean. J. Geophys. Res., $81: 2605-2616$.

Kolla, V., and Coumes, F., 1987. Morphology, internal structure, seismic stratigraphy, and sedimentation of Indus Fan. AAPG Bull., 71: 650-677.

Kolla, V., Kostecki, J. A., Robinson, F., and Biscaye, P. E., 1981. Distribution and origins of clay minerals and quartz in surface sediments of the Arabian Sea. J. Sediment. Petrol., 51:563-569.

Matter, A., 1974. Burial diagenesis of pelitic and carbonate deep-sea sediments from the Arabian Sea. In Whitmarsh, R. B., Weser, O. E., Ross, D. A., et al., Init. Repts. DSDP, 23: Washington (U.S. Govt. Printing Office), 421-470.

Meade, R. H., 1966. Factors influencing the early stages of the compaction of clays and sands-review. J. Sediment. Petrol., 36:1085-1101.

Mitchell, J. K., 1976. Fundamentals of Soil Behavior: New York (Wiley).

Moon, C. F., and Hurst, C. W., 1984. Fabric of muds and shales: an overview. In Stow, D.A.V., and Piper, D.J.W. (Eds.), Fine-Grained Sediments: Deep-Water Processes and Facies: Oxford (Blackwell), 579-593.

Müller, F., 1967. Methods in Sedimentary Petrology: New York (Hafner).

O'Brien, N. R., 1987. The effects of bioturbation on the fabric of shale. J. Sediment. Petrol., 57:449-455.

Odom, E. J., 1967. Clay fabric and its relation to structural properties in mid-continent Pennsylvanian sediments. J. Sediment. Petrol., 37: 610-623.

Prell, W. L., Niitsuma, N., et al., 1989. Proc. ODP, Init. Repts., 117: College Station, TX (Ocean Drilling Program).

Pusch, R., 1973. Influence of organic matter on the geotechnical properties of clays. Natl. Swed. Bldg. Res., 11.

Reimers, C. E., 1982. Organic matter in anoxic sediments off central Peru: relations of porosity, microbial decomposition and deformation properties. Mar. Geol., 46:175-197.

Schlanger, S. O., and Douglas, R. G., 1974. The pelagic ooze-chalklimestone transition and its implication for marine stratigraphy. Spec. Publ. Int. Assoc. Sedimentol., 1:117-148.

Date of initial receipt: 24 August 1989

Date of acceptance: 20 February 1990

Ms 117B-151 